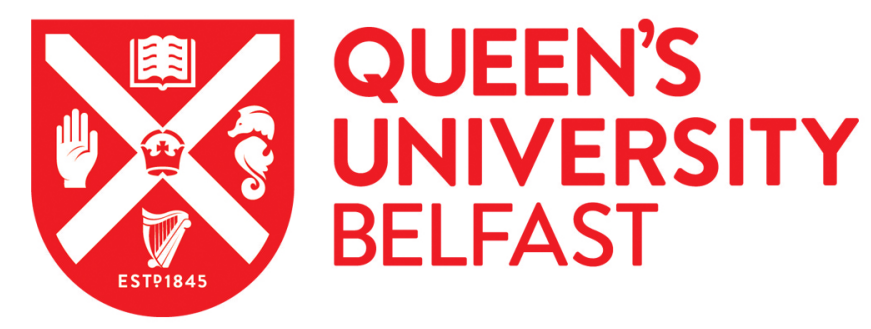

\title{
What is the most energy efficient route for biogas utilization: Heat, electricity or transport?
}

Hakawati, R., Smyth, B., McCullough, G., deRosa, F., \& Rooney, D. (2017). What is the most energy efficient route for biogas utilization: Heat, electricity or transport? Applied Energy, 206, 1076-1087.

https://doi.org/10.1016/j.apenergy.2017.08.068

\section{Published in:}

Applied Energy

\section{Document Version:}

Peer reviewed version

Queen's University Belfast - Research Portal:

Link to publication record in Queen's University Belfast Research Portal

\section{Publisher rights}

Copyright 2017 Elsevier.

This manuscript is distributed under a Creative Commons Attribution-NonCommercial-NoDerivs License

(https://creativecommons.org/licenses/by-nc-nd/4.0/), which permits distribution and reproduction for non-commercial purposes, provided the author and source are cited.

\section{General rights}

Copyright for the publications made accessible via the Queen's University Belfast Research Portal is retained by the author(s) and / or other copyright owners and it is a condition of accessing these publications that users recognise and abide by the legal requirements associated with these rights.

Take down policy

The Research Portal is Queen's institutional repository that provides access to Queen's research output. Every effort has been made to ensure that content in the Research Portal does not infringe any person's rights, or applicable UK laws. If you discover content in the Research Portal that you believe breaches copyright or violates any law, please contact openaccess@qub.ac.uk. 


\title{
What is the most energy efficient route for biogas utilization: heat, lectricity or transport?
}

Rawan Hakawatia, Beatrice M. Smythb*, Geoffrey McCulloughb, Fabio De Rosaa, David Rooneya

\author{
a School of Chemistry \& Chemical Engineering, Queen's University \\ Belfast, N. Ireland BT9 5AG
}

b School of Mechanical \& Aerospace Engineering, Queen's University Belfast, N. Ireland BT9 5AH

*Corresponding author: beatrice.smyth@qub.ac.uk, +44 2890974318

\section{Abstract}

\section{Introduction}

The target set by the EU Renewable Energy Directive (2009/28/EC) [1] requires a 20\% energy share from renewable sources by 2020 . Thus, exploring alternative, environmentally benign and energy efficient systems has become the focus of governmental policies and industrial as well as academic research. Biogas is a renewable energy source that can be produced from the anaerobic digestion (AD) of biomass, such as sewage sludge, municipal solid waste, agricultural wastes, and energy crops. Biogas consists of around $50-60 \%$ methane $\left(\mathrm{CH}_{4}\right), 40-50 \%$ carbon dioxide $\left(\mathrm{CO}_{2}\right)$ and some minor constituents, such as hydrogen sulphide $\left(\mathrm{H}_{2} \mathrm{~S}\right)$ and water. The use of biogas for energy production could displace fossil fuels, reduce greenhouse gas emissions and decrease dependence on imported energy [2].

Upgraded biogas, termed bio-methane, is typically composed of $\sim 97 \% \mathrm{CH}_{4}$ and $\sim 3 \% \mathrm{CO}_{2}$, and is converted to the same standard as natural gas through removal of $\mathrm{CO}_{2}$ (upgrading) and other impurities (cleaning). Another route for upgrading biogas to bio-methane involves the chemical transformation of $\mathrm{CO}_{2}$ to $\mathrm{CH}_{4}$ by 
the Sabatier reaction (equation 1); the hydrogen $\left(\mathrm{H}_{2}\right)$ in the reaction is usually obtained from water $\left(\mathrm{H}_{2} \mathrm{O}\right)$ electrolysis (equation 2). This combined pathway could have an important impact on the global carbon cycle [3]. There are various utilization pathways for both raw and upgraded forms of biogas [4]; commercial methods include electricity and heat generation via combined heat and power (CHP) units, electricity generation via fuel cells, and conversion to mechanical energy for transport via internal combustion engines (ICEs). Bio-methane can be injected into the gas grid, and/or converted to compressed renewable natural gas or liquefied renewable natural gas (referred to in this paper as CNG and LNG respectively) to serve as a transport fuel. Biogas can also be reformed to syngas ( $\mathrm{CO}$ and $\mathrm{H}_{2}$ ) for liquid fuel production via Fischer Tropsch (FT) synthesis (see [5] for further details).

$\mathrm{CO}_{2}+4 \mathrm{H}_{2} \rightarrow \mathrm{CH}_{4}+2 \mathrm{H}_{2} \mathrm{O}$

$2 \mathrm{H}_{2} \mathrm{O} \rightarrow 2 \mathrm{H}_{2}+\mathrm{O}_{2}$

As with any new energy system, countries are faced with ongoing challenges when designing the most optimum pathway to ensure sustainable development and sufficient energy supply [6]. In practice, many European countries have successfully integrated biogas into their energy sectors via different utilization routes. The annual energy production from biogas is around $42 \mathrm{TWh}$ in Germany (the highest production in the EU), 9 TWh in UK, and 2.8 TWh in France; in each of these countries the biogas is mainly used for electricity generation [7]. Sweden produces around $1.7 \mathrm{TWh}$ from biogas and $44 \%$ of biogas production is upgraded to bio-methane and used as vehicle fuel [8]. In Italy, biogas is mainly used for power generation while other pathways such as grid injection and CHP require further exploration [9]. However, although there are various options for biogas utilization, there is limited guidance in the literature on the selection of the optimum route.

A number of papers focus specifically on biogas utilization as a vehicle fuel $[9,10]$ while others assess certain aspects of potential biogas utilization methods. Pöschl et al. [11] consider the energy efficiency of CHP, upgrading, gas turbine and fuel cell pathways within the biogas system, but the focus is mainly on the impact of feedstock and scale on the overall energy balance. Chen et al. [12] looked at the energy conversion efficiency of a single biogas reforming technique under $\mathrm{O}_{2}$ concentrations but did not investigate syngas utilization options. Friesenhan et al. [13] looked at the energy efficiency of three utilization routes specifically for landfill biogas. Djatkov et al. [14] investigated the energy efficiency of agricultural biogas plants using manure as feedstock material and analysed the use of biogas in a single route, in a CHP plant. Goulding and Power [15] look at the direct use of biogas in a CHP unit, and its 
upgrading to bio-methane for use as transport fuel in Ireland, from an economic and energy point of view. Börjesson and Berglund [16] conduct an environmental evaluation of biogas to CHP, while Morero et al. [17] tackle environmental and economic assessment of biogas upgrading. In both cases energetic performance is neglected. Wu et al. [18] present a comprehensive assessment from an energetic, economic and environmental point of view targeting three pathways (CHP, upgrading and fuel cell) for electricity production only.

Based on the information in the literature, three main issues can be identified: (i) there is no complete biogas framework of the numerous possible interlinked routes serving three final useful forms of energy (electricity, heat, and mechanical energy for transport), (ii) the criteria (economic, technical, energy efficiency, social or environmental etc.) used for route evaluation vary between studies and direct comparison between different studies is therefore not possible, and (iii) the system boundary conditions are often not clearly defined and involve different site locations as well as different feedstocks. Thus in order to choose the most suitable alternative and allow direct comparison amongst possible routes, there is a need to develop a consistent framework of predefined boundary conditions focused on specific criteria.

To develop the framework, decision making tools are needed [19]. One such tool is technology road mapping for strategic planning, which can help countries decide on investments; however this tool is very resource intensive and location specific as it requires extensive research and collaboration amongst experts [6]. Life cycle assessment (LCA) is an alternative method which is considered one of the most suitable tools that allows a uniform assessment of a biofuel system [20]. LCA should include defined functional unit (criteria of study), system boundaries (consistent) and a defined methodology [20]. Decision making tools should be informed by solid scientific data and, although technical, political, social and economic factors are all important parts of the decision making toolbox, Trianni et al. [21] has reported that energy efficiency is considered the primary factor (criteria) of competitiveness amongst enterprises.

In this paper, different biogas-to-energy exploitation routes were evaluated using a comprehensive LCA, a tool for system analysis, focusing on energy efficiency as the chosen criteria. The resulting framework of energy efficiencies allows the direct comparison of numerous routes while identifying opportunities for process development. The work done developed an assessment tool that appraises biogas-to-energy routes in an objective manner. The results can be incorporated into wider studies that include elements 
that are specific to local regions or plants, thus providing the basis for further research on optimizing the sustainability of biogas-to-energy systems.

\section{Methodology}

\subsection{Overview}

Tracing the flow of energy through the industrial system is necessary to critically evaluate the sustainability of energy systems and components [22].The energy analysis of the alternative routes for biogas utilization was conducted using LCA techniques. LCA is defined as a technique to address the environmental aspects and potential impacts associated with a product, process or service [23]. The standard LCA framework was followed for this analysis: goal and scope definition; inventory analysis and impact assessment; and interpretation.

\subsection{Goal and scope definition}

\subsubsection{Boundary conditions}

The goal of this LCA was to investigate the energy balance of alternative routes for biogas utilization, and to identify the most energy efficient utilization pathway. The scope of the analysis started with clean biogas at $60 \% \mathrm{CH}_{4}$ and $40 \% \mathrm{CO}_{2}$ (without impurities such as Sulphur) and ended with its transformation to a useful form of energy as either heat, mechanical energy for transportation, or electricity (Fig 1). The boundary included routes involving the direct use of raw biogas, as well as the production of intermediate fuels from biogas (such as syngas from reforming and bio-methane from upgrading) and ancillary processes such as electrolysis. For the base case analysis, only direct energy was taken into account. Direct energy is that used directly in the system (for example, electricity used for upgrading), while indirect energy is that used to produce a material which is then used within the system boundaries (for example, the energy to produce the fuels which are then used to generate the electricity used within the boundaries).

Fuel carriers such as pipelines and road haulage were omitted, as the associated energy demands are highly site specific and can vary from zero in the case of distribution through the local gas network [24] to approximately $1.5 \mathrm{MJ} / \mathrm{km}$ for transport on an average laden heavy goods vehicle [25] (not including the energy for compression and chilling). Feedstock production and the anaerobic digestion process were also outside the analysis boundary, as was the end user's specific equipment for electricity or heat utilization, for example, the efficiency of an electrical appliance (although a sensitivity analysis expanded the boundaries to compare electric vehicles to ICE vehicles). The selected base case boundary conditions 
ensured that the results of the energy balance assessment were directly comparable between biogas utilization routes.

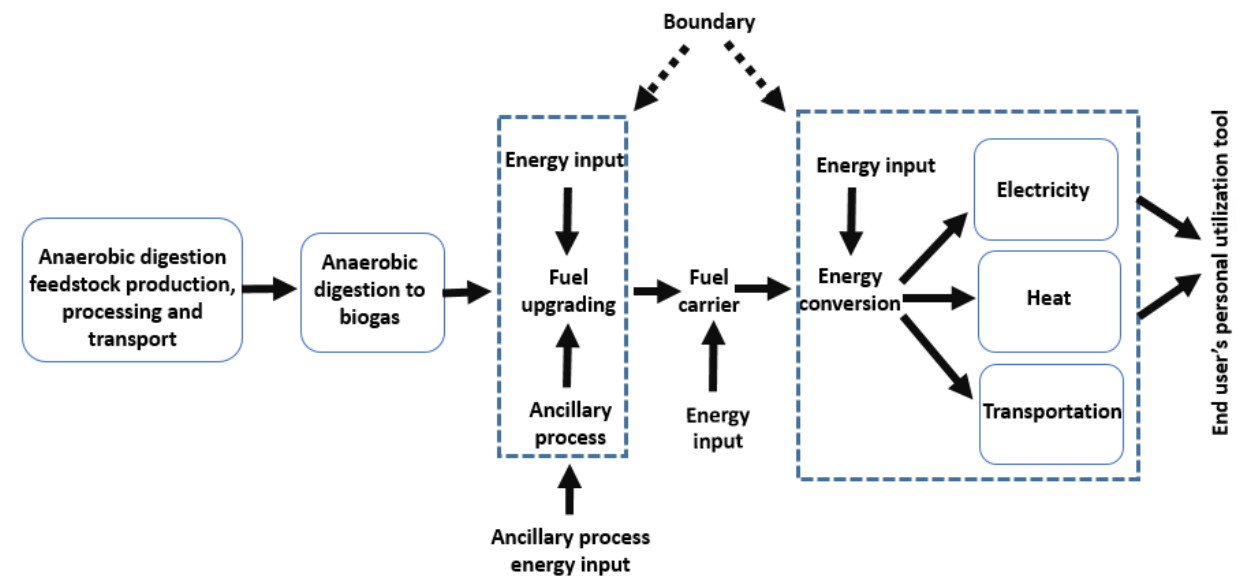

Fig 1: Schematic diagram of the LCA's boundary conditions

A detailed flow diagram of the biogas exploitation network (Fig 2) developed using Gliffy, an online diagramming tool, showed the routes investigated for biogas exploitation, grouping the results into four categories according to the final useful form of energy:

- Electricity: routes via a power station, CHP unit (excluding thermal efficiency), and fuel cell

- Heat: routes via a boiler

- Electricity and heat: routes via a power station, CHP unit (including both thermal and electrical efficiency), and fuel cell

- Mechanical energy for transport: routes via ICE (for ICE vehicles), and power station (for electric vehicles)

Compressing bio-methane to CNG was only included as an option prior to its use in an ICE for transport and was excluded from the electricity and heat routes because of associated logistical difficulties; LNG was the preferred option for bulk transportation of gas for off-grid applications. 

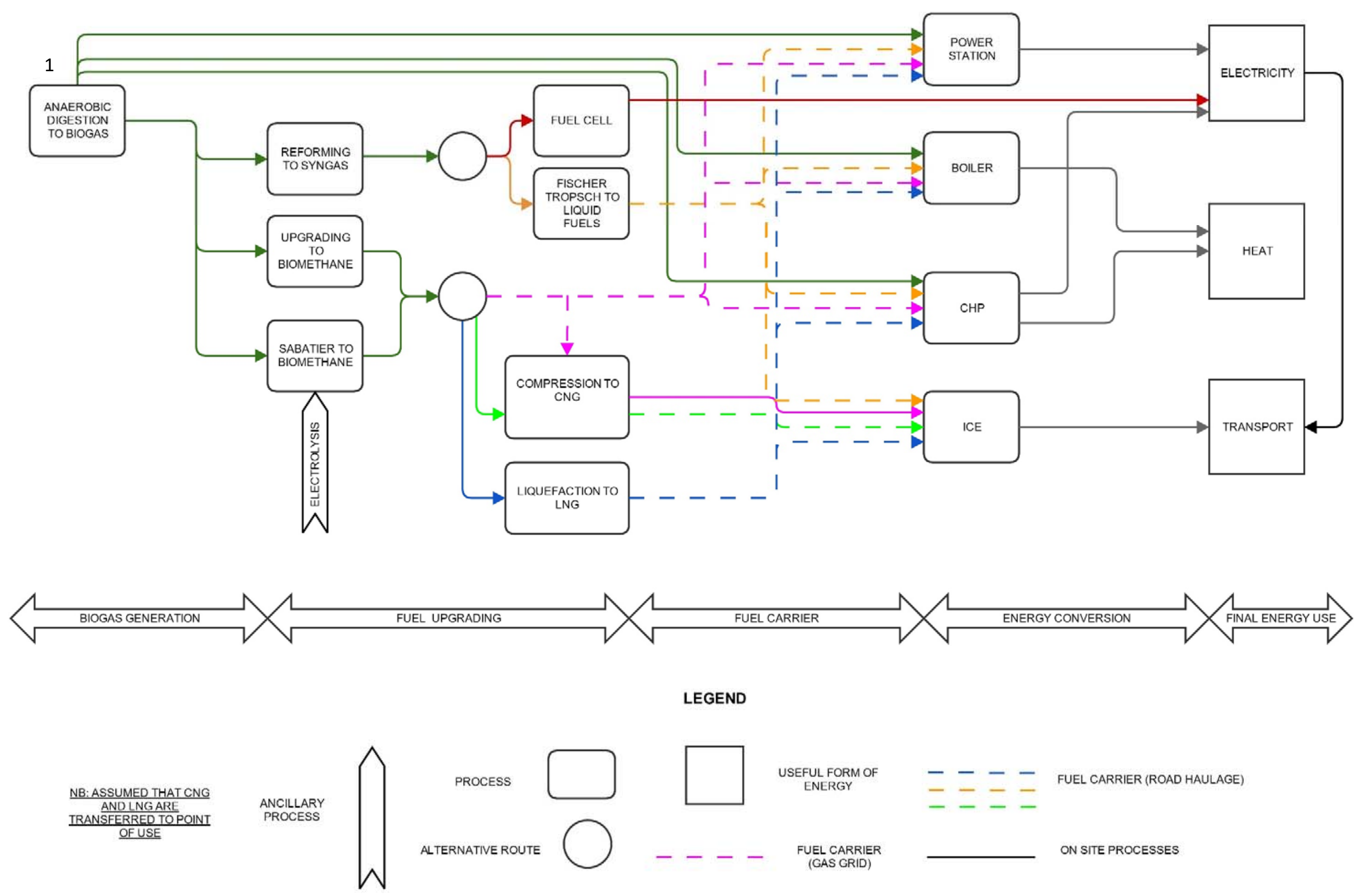

Fig 2: Schematic diagram showing biogas exploitation network categorized according to the final useful form of energy (electricity, heat or transport) 


\subsubsection{Functional unit}

The functional unit (criteria of assessment) defines precisely what is being studied, and is the unit through which the system is analysed. For this analysis, the energy balance of a system was assessed in terms of "\% energy efficiency", which is defined as the proportion of total energy input that was transformed to useful energy (energy in and energy out respectively in Fig 3). Each biogas exploitation route consisted of a series of components operating sequentially, and each individual component introduced its own efficiency $\left(\eta_{x}\right)$ to the route as a whole. The overall route energy efficiency ( $\left.\eta_{\text {route }}\right)$ was calculated by multiplying the individual component efficiencies together (Fig 3/equation 3).

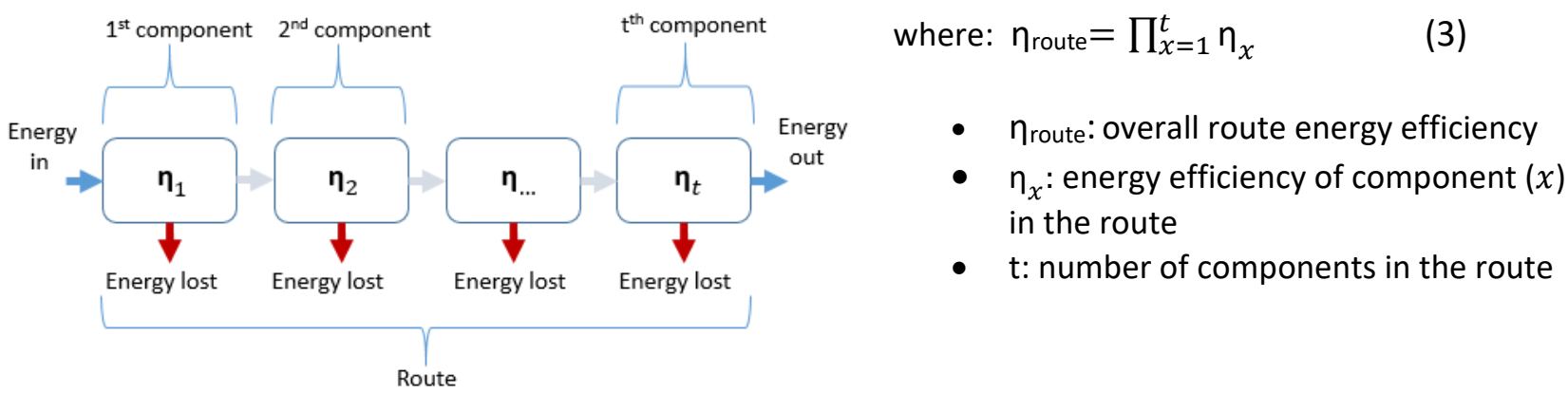

Fig 3: Biogas route efficiency calculation

\subsection{Inventory analysis and impact assessment}

The individual efficiencies of route components $\left(\eta_{x}\right)$ were found via one of two methods. Method 1 (equation 4) was used to determine standard component efficiencies for specific equipment (for example, boiler, CHP unit, fuel cell) (Table 1). Method 2 (equation 5) was followed when simulations were needed for component efficiency calculations (for example, biogas reforming to syngas and FT synthesis, refer to Supplementary Data A).

Method 1: $\eta_{x}=\frac{\text { Energy }_{\text {out }}(J)}{\operatorname{Energy~}_{\text {in }}(J)} \times 100$

Method 2: $\eta_{x}=\frac{\text { Energy }_{\text {out }}(J)}{\operatorname{Energy~}_{\text {in }}(J)}=\frac{\sum L H V_{\text {out }, a} m_{\text {out }, a}}{\sum L H V_{\text {in }, b} m_{\text {in }, b}+Q_{\text {supplied }}} \times 100$

where:

- $\mathrm{LHV}_{\text {out } / \mathrm{in}}$ : lower heating value of the input (b) or output (a) material $(\mathrm{J} / \mathrm{mol})$

- $\mathrm{m}_{\text {out} / \text { in: }}$ molar flow rate of input (a) or output (b) material (mol/s)

- $Q_{\text {supplied: }}$ power supplied (J/s). 


\begin{tabular}{|c|c|c|c|}
\hline Equipment & Specification & Efficiency (\%) & Source \\
\hline ICE & $\begin{array}{l}\text { Tank-to-wheel efficiency includes energy storage (e.g. fuel in } \\
\text { the tank), the energy conversion in the engine (e.g. ICE), plus } \\
\text { losses. Reported at } 18.1 \% \text { but assumed } 20 \% \text { for this paper. }\end{array}$ & 20 & [26] \\
\hline CHP & Efficiency based on the LHV of the fuel for a $5 \mathrm{MW}$ unit. & 40 (electrical), 50 (heat) & [27-29] \\
\hline $\begin{array}{l}\text { Pressurized water } \\
\text { scrubber }\end{array}$ & $\begin{array}{l}\text { Standard energy efficiency based on methane's LHV and final } \\
\text { concentration is between } 90-96 \% \text { with a methane slip of } 0.5- \\
2 \% \text {. An average of } 93 \% \text { was assumed. }\end{array}$ & 93 & [30] \\
\hline Boiler & $\begin{array}{l}\text { Efficiency based on } 100 \mathrm{~kW} \text { unit calculated as heat energy } \\
\text { output ( } \mathrm{kWh} \text { ) divided by energy input (kWh) (biogas energy } \\
\text { content). An average of } 82.5 \% \text { was assumed }\end{array}$ & 82.5 & [31] \\
\hline Solid oxide fuel cell (SOFC) & $\begin{array}{l}\text { Efficiency based on } 7 \mathrm{~kW} \text { unit and calculated as useful energy } \\
\text { output/energy input. SOFCs were chosen as they are } \\
\text { contaminant-resistant (can endure presence of CO). }\end{array}$ & 50 & [32] \\
\hline Liquefaction & $\begin{array}{l}\text { Efficiency calculated as energy output/energy input. A Cryostar } \\
\text { closed nitrogen reversed Brayton cycle liquefaction system } \\
\text { was assumed (electricity consumed was } 0.63 \mathrm{kWh} / \mathrm{Nm}^{3} \text { clean } \\
\text { gas }=2.268 \mathrm{MJ} / \mathrm{m}^{3} ; 1 \mathrm{Nm}^{3} \text { of clean biogas is equivalent to } 31.8 \\
\mathrm{MJ} / \mathrm{m}^{3} \text {, thus energy output is } 31.8-2.268=29.532 \mathrm{MJ} / \mathrm{m}^{3}\end{array}$ & 92 & [33] \\
\hline Compression & $\begin{array}{l}\text { Efficiency calculated based on energy output/energy input. } \\
\text { Energy input is } 0.35-0.6257 \mathrm{kWh} / \mathrm{m}^{3} \text { of bio-methane. A value of } \\
0.35 \mathrm{kWh} / \mathrm{m}^{3} \text { was assumed for this paper. }\end{array}$ & 96 & [24] \\
\hline Sabatier + electrolysis & $\begin{array}{l}\text { The Sabatier process is } 98 \% \text { efficient. For Stuart's and Norsk } \\
\text { Hydro's bipolar alkaline electrolyser, efficiency is } 73 \% \text { (based on } \\
\text { energy output relative to input), but improved manufacturing } \\
\text { electrolysers can reach } 78 \% \text {; the average electrolysis efficiency } \\
\text { of } 74 \% \text { was assumed for this paper. }\end{array}$ & 74 & {$[34,35]$} \\
\hline $\begin{array}{l}\text { Biogas power station } \\
\text { (BPS) }\end{array}$ & $\begin{array}{l}\text { Electrical efficiency defined as electricity output/energy input } \\
\text { (LHV basis). }\end{array}$ & 35 & [32] \\
\hline $\begin{array}{l}\text { Gas fired CCGT power } \\
\text { station (GPS) }\end{array}$ & $\begin{array}{l}\text { Electrical efficiency defined as electricity output/energy input } \\
\text { (based on LHV). In a CCGT GPS (typical power plant size } 250 \\
\text { MW), electricity is generated more efficiently than in a single } \\
\text { gas turbine cycle because the exhaust heat is recovered via a } \\
\text { heat recovery steam generator. }\end{array}$ & 58 & [32] \\
\hline $\begin{array}{l}\text { Fuel oil power station } \\
\text { (OPS) }\end{array}$ & $\begin{array}{l}\text { Efficiency values for electricity generation in an average thermal } \\
\text { power plant }(>100 \mathrm{MW}) \text {. }\end{array}$ & 40 & [32] \\
\hline
\end{tabular}


Reforming reactions tend to be catalyst specific [36] or conducted with certain chemical additions to enhance efficiency [37]. The reforming reactions were evaluated based on preliminary simulations using Aspen Plus ${ }^{\circledast}$, a modelling tool for conceptual design, performance monitoring and optimization [38], which allows the breakdown of the process into its hierarchical sections. The available online Aspen Plus ${ }^{\circledR}$ tutorials along with the initial conditions for methane steam reforming [39] (Table 2) were used as a starting point to generate the overall simulations. $1 \mathrm{~mol} / \mathrm{s}$ of biogas at $60 \% \mathrm{CH}_{4}$ and $40 \% \mathrm{CO}_{2}$ was assumed as the base unit except in the case when $\mathrm{CO}_{2}$ was not needed (steam reforming), where $0.6 \mathrm{~mol} / \mathrm{s}$ of $\mathrm{CH}_{4}$ was assumed as the base unit.

This analysis considered six different reforming options for syngas production (Table 3). The simulation of methane steam reforming (Fig 4) used a Gibbs reactor to carry out reaction calculations based on minimizing the Gibbs energy for the system without the need for detailed stoichiometry or yield. Other reforming processes (Table 3 ) were simulated similarly on Aspen Plus ${ }^{\circledR}$ following operating conditions from the literature [40]. Auto-thermal reforming (ATR) of methane steam, dry and tri-reforming are coupled with a partial oxidation reaction (exothermic); the heat supplied by partial oxidation was completely used by the subsequent endothermic reforming reactions [40], so no input power is required in the simulations.

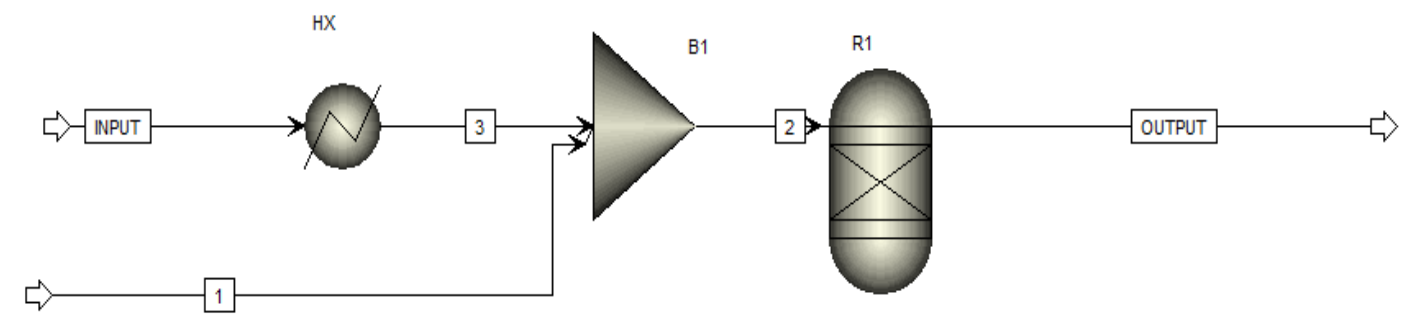

Fig 4: Methane steam reforming Aspen simulation (further explained in Table 2)

Table 2: Aspen assumptions for methane steam reforming

\begin{tabular}{llll}
\hline Stream & Explanation & Symbol & Explanation \\
\hline Input & $\mathrm{CH}_{4}$ and $\mathrm{H}_{2} \mathrm{O}$ & $\mathrm{Hx}$ & Heater \\
\hline Output & $\mathrm{CO}$ and $\mathrm{H}_{2}$ & $\mathrm{~B} 1$ & Mixer \\
\hline $\mathbf{1}$ & $\mathrm{H}_{2} \mathrm{O}$ & $\mathrm{R} 1$ & Gibbs reactor \\
\hline $\mathbf{2}$ & $\mathrm{H}_{2} \mathrm{O}$ and $\mathrm{CH}_{4}$ & & \\
\hline $\mathbf{3}$ & Heated $\mathrm{CH}_{4}$ and $\mathrm{CO}_{2}$ & & \\
\hline
\end{tabular}

\begin{tabular}{lc}
\hline & Assumptions \\
\hline Feed conditions & $\mathrm{H}_{2} \mathrm{O} / \mathrm{CH}_{4}: 3 / 1$ and $\mathrm{CH}_{4} 0.6 \mathrm{~mol} / \mathrm{s}$ \\
\hline
\end{tabular}




\begin{tabular}{ll}
\hline Feed temperature & $25^{\circ} \mathrm{C}$ \\
\hline Feed pressure & $1 \mathrm{bar}$ \\
\hline Process pressure & $1 \mathrm{bar}$ \\
\hline Process temperature & $800^{\circ} \mathrm{C}$ \\
\hline Equation of state & Peng Robinson \\
\hline
\end{tabular}

The output or input materials in equation 5 varied depending on the specific requirements of the subsequent process in the production chain. For example, FT synthesis required syngas $\left(\mathrm{CO}\right.$ and $\left.\mathrm{H}_{2}\right)$ as an input material, and syngas was therefore the output material from reforming in this case. For a fuel cell, however, the useful input material was only $\mathrm{H}_{2}$. Reforming efficiency depended on the process; it was calculated with $\mathrm{H}_{2}$ and $\mathrm{CO}$ as useful output materials when used for FT synthesis, and with only $\mathrm{H}_{2}$ when used for a fuel cell. The power supplied $\left(\mathrm{Q}_{\text {supplied }}\right)$ in the reforming calculations was the "heat duty" output from the Aspen Plus ${ }^{\circledR}$ simulations (further information on the reforming calculations and the associated datasets are presented in Supplementary Data A).

Typical low-temperature FT operating conditions $\left(250^{\circ} \mathrm{C}\right.$ and 20 bar) were assumed for this analysis, as these conditions resulted in the most substantial production of liquid fraction $\left(\mathrm{C}_{5}-\mathrm{C}_{22}\right)$ at $33 \%$ weight of total output [41]. Power supplied $\left(\mathrm{Q}_{\text {supplied }}\right)$ was assumed to be due to compression to 20 bar [5]. This referred to the power needed to compress $1 \mathrm{~mol} / \mathrm{s}$ of syngas and was calculated according to Ashraf et al. [42]. FT component efficiencies were calculated based on syngas input flow rates obtained from reforming simulations summed with the FT products in the $C_{5}-C_{22}$ range (equation 5) (see Supplementary Data A for further details). Cobalt-based low temperature FT was assumed; cobalt-based catalysts are the most commonly used for commercial liquid fuel production [41].

Table 3: Oxidation, reforming and FT synthesis reactions involved in the analysis

\begin{tabular}{lll}
\hline Oxidation reactions & & $\mathrm{H}_{2} / \mathrm{CO}^{(\text {a) }}$ \\
\hline Partial-oxidation reforming (POx) & $\mathrm{CH}_{4}+\mathbf{0 . 5 O}_{2} \rightarrow \mathrm{CO}+2 \mathrm{H}_{2}$ & $\mathrm{~N} / \mathrm{A}$ \\
\hline Total oxidation (TOx) & $\mathrm{CH}_{4}+2 \mathrm{O}_{2} \rightarrow \mathrm{CO}_{2}+2 \mathrm{H}_{2} \mathrm{O}$ & $\mathrm{N} / \mathrm{A}$ \\
\hline Reforming reactions & & \\
\hline Methane steam reforming (SR) & $\mathrm{CH}_{4}+\mathrm{H}_{2} \mathrm{O} \rightarrow \mathrm{CO}+3 \mathrm{H}_{2}$ & 3 \\
\hline Dry reforming (DR) & $\mathrm{CH}_{4}+\mathrm{CO}_{2} \rightarrow 2 \mathrm{CO}+2 \mathrm{H}_{2}$ & 1.6 \\
\hline Tri-reforming (TR) & $\mathrm{SR}+\mathrm{DR}+\mathrm{POx}+\mathrm{TOx}$ & 1.55 \\
\hline SR (ATR) & $\mathrm{SR}+\mathrm{POx}$ & 5 \\
\hline DR (ATR) & $\mathrm{DR}+\mathrm{POx}$ & 1.22 \\
\hline TR (ATR) & & 1.55 \\
\hline
\end{tabular}

Fischer Tropsch main polymerization reactions 


\begin{tabular}{|c|c|c|}
\hline Paraffin & $(2 \mathrm{n}+1) \mathrm{H}_{2}+\mathrm{nCO} \rightarrow \mathrm{C}_{\mathrm{n}} \mathrm{H}_{2 n+2}+$ & $\mathrm{N} / \mathrm{A}$ \\
\hline \multicolumn{3}{|l|}{$\mathrm{nH}_{2} \mathrm{O}$} \\
\hline Olefins & $2 \mathrm{nH}_{2}+\mathrm{nCO} \rightarrow \mathrm{C}_{\mathrm{n}} \mathrm{H}_{2 \mathrm{n}}+\mathrm{nH}_{2} \mathrm{O}$ & N/A \\
\hline
\end{tabular}

(a) Obtained from Aspen simulations at $800^{\circ} \mathrm{C}$.

(b) The $\mathrm{O}_{2}$ molar flow rate in Aspen was adjusted in a way that minimized the power needed (heat duty) to drive the reaction forward until that value reached $0 \mathrm{~W}$.

\subsection{Interpretation}

For certain routes, intermediate fuels were needed in the process of transforming biogas to the final useful form of energy (Table 4); depending on the properties of the intermediate fuels, different energy conversion processes were required to reach the final useful form of energy. Component efficiency diagrams were used to show individual component efficiencies for different routes grouped depending on the final use of energy (electricity, heat, electricity and heat, and transportation). Each route's overall energy efficiency (calculated using equation 3 ) was compared to other routes in the same group (electricity, heat, electricity and heat, and transportation).

Table 4: Energy densities of biogas and intermediate fuels

\begin{tabular}{lll}
\hline Raw fuel & Energy density (MJ/I) & Notes \\
\hline Biogas $^{(\text {a) }}$ & 0.02268 & $60 \%$ methane \\
\hline Intermediate fuel & Energy density (MJ/I) & Notes \\
\hline Syngas $^{(\text {a) }}$ & 0.0182 & $\begin{array}{l}50 \% \text { energy density of natural gas, } \\
{[43]}\end{array}$ \\
& & {$[44]$} \\
\hline Liquid fuels $^{(\text {a) }}$ & 33.5 & {$[24]$} \\
\hline Methane $^{\text {(a) }}$ & 0.0378 & {$[45]$} \\
\hline Liquid methane & \\
$\begin{array}{l}\text { (a) } \text { At NTP of } 1.013 \text { bar and } 25^{\circ} \mathrm{C} . \\
\text { (b) At 0-8 bar overpressure and }-162^{\circ} \mathrm{C} \text { to }-130^{\circ} \mathrm{C} .\end{array}$
\end{tabular}

\section{Results and analysis}

\subsection{Electricity generation}

The route biogas follows can be direct, corresponding to the use of raw biogas in a power station or CHP unit (routes E1 and E2), or indirect requiring intermediate processing (routes E3-E6). For example, an indirect route is the reforming of biogas to syngas via tri-reforming, after which it is sent to a FT synthesis unit to produce liquid fuels. Routes (Fig 5) were arranged according to the intermediate fuel of choice:

1. No intermediate fuel (biogas used directly): routes E1-E2

2. Syngas: routes E3.1-E3.6

3. Liquid fuels: routes E4.1-E4.12 


\section{Bio-methane: routes E5.1-E5.4}

5. Liquid bio-methane: routes E6.1-E6.4

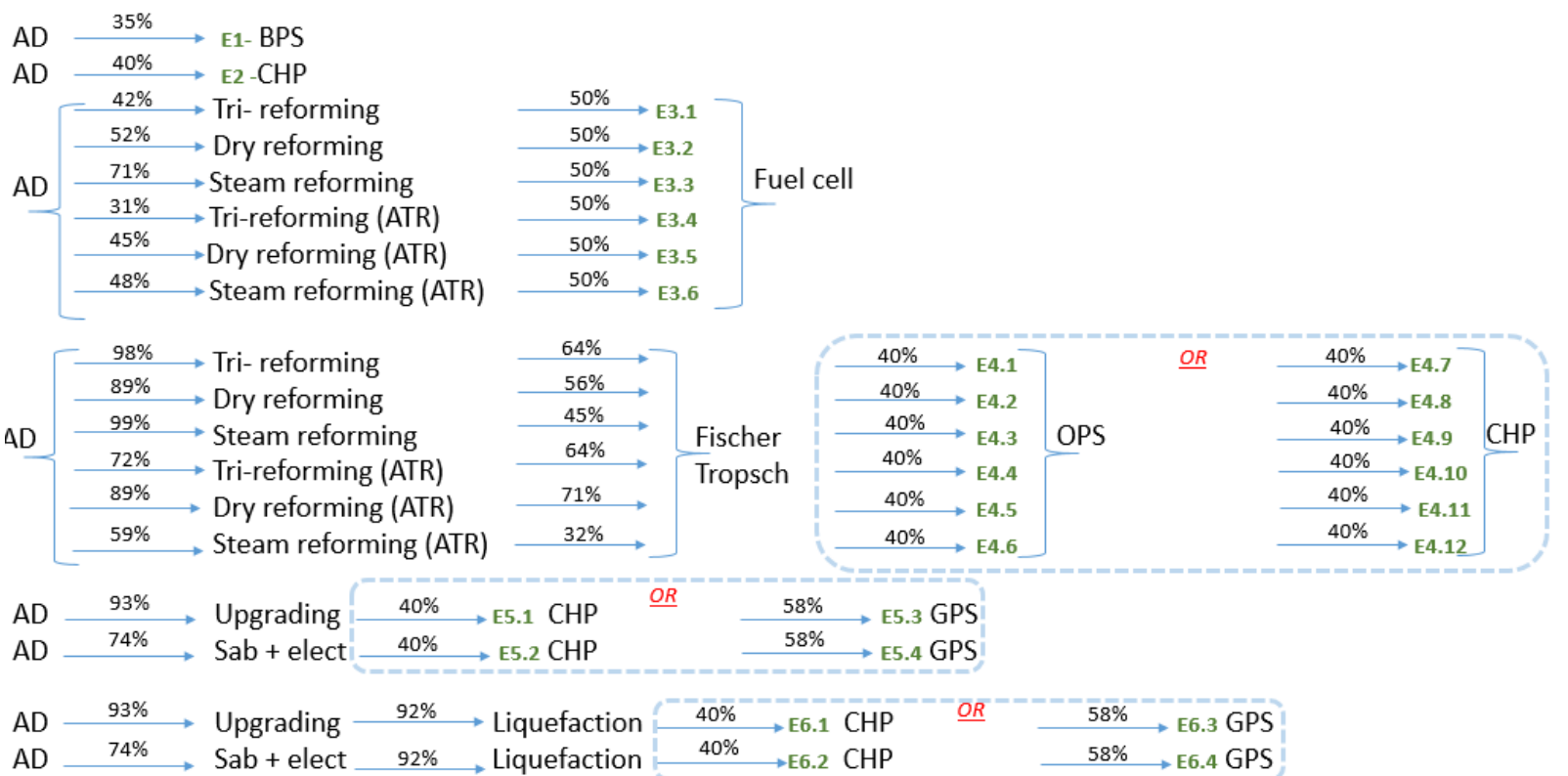

BPS: Biogas power station; ATR: Auto-thermal ; OPS: Oil power station; CHP: Combined heat and power; GPS: Gas power station

Fig 5: Component efficiency diagram for routes involved in electricity generation

Routes' overall energy efficiencies (Fig 6) showed a maximum of $54 \%$ for biogas upgrading to biomethane subsequently used in a CCGT gas power station (GPS) (route E5.3), and a minimum of $8 \%$ for methane steam reforming (ATR) used for FT synthesis (routes E4.6 and E4.12). The overall efficiencies for routes undergoing FT synthesis varied from $<10 \%$ to $>20 \%$. This variation was due to the fact that different reforming processes result in different $\mathrm{H}_{2} / \mathrm{CO}$ ratios, some of which were more suited to FT synthesis than others; the most suitable $\mathrm{H}_{2} / \mathrm{CO}$ ratios are between 1 and 2.1 [40, 42]. The low efficiency for routes E4.6 and E4.12 was due to the methane steam reforming (ATR) reaction's high $\mathrm{H}_{2} / \mathrm{CO}$ ratio of 5 . However, other reforming processes showed higher efficiencies and a high of $25 \%$ was achieved with dry reforming (ATR) (routes E4.5 and E4.11).

Fuel cell utilization had efficiencies ranging from $16 \%$ to $25 \%$ (routes E3.1-E3.6). Fuel cell deployment is at an advanced stage of development in certain regions, for example Germany, as it is associated with low emissions and relatively high efficiencies [11]. Upgrading biogas to bio-methane for gas grid injection and use off-site in a CHP unit achieved an efficiency of $37 \%$ (route E5.1). For off-site use in locations not on the gas grid, upgraded biogas was liquefied (routes E6.1-E6.4) for power or CHP generation with overall efficiencies varying from $27 \%$ to $50 \%$. The continuous chilling required to keep LNG at the condensation temperature of methane $\left(-161^{\circ} \mathrm{C}\right)$ is an energy intensive process [33] that would further decrease the route's overall energy efficiency.

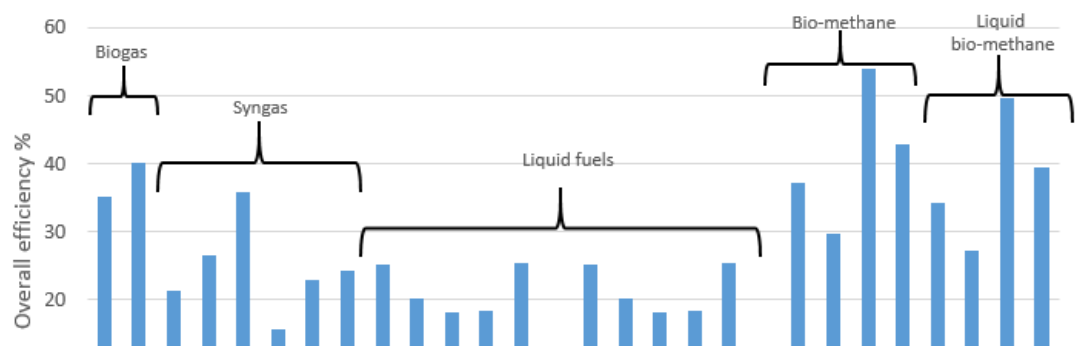


Fig 6: Routes' overall energy efficiencies for electricity generation

\subsection{Heat generation}

Boilers apply heat produced from the combustion of a fuel to a fluid (for example, water). Component efficiencies (Fig 7) for routes involving boilers varied between $16 \%$ and $83 \%$. The highest overall energy efficiency (Fig 8) was $82 \%$ for the direct utilization of biogas via a boiler (route $\mathrm{H} 1$ ), while the lowest at $16 \%$ was when FT liquid fuels from steam reforming (ATR) were used in a boiler (route H2.6). While processes can be improved through waste heat recovery, the heat released from the exothermic FT synthesis reaction is of low grade and is generally wasted [46]. Biogas upgrading to bio-methane (route H3.1) was more efficient (77\%) than the Sabatier and electrolysis process (61\%) (route H3.2).

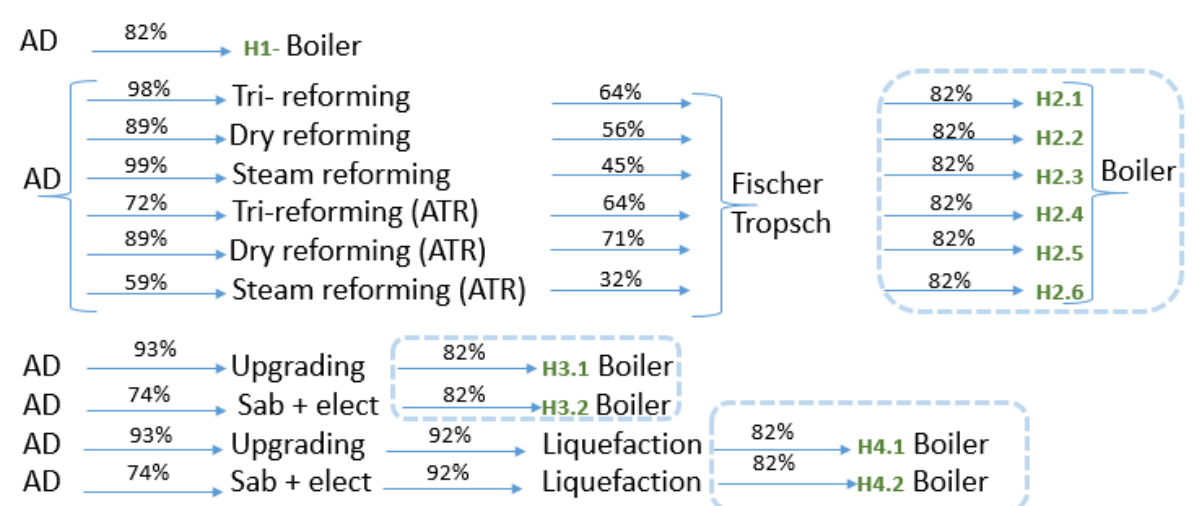

ATR: Auto-thermal

Fig 7: Component efficiency diagram for routes involved in heat generation

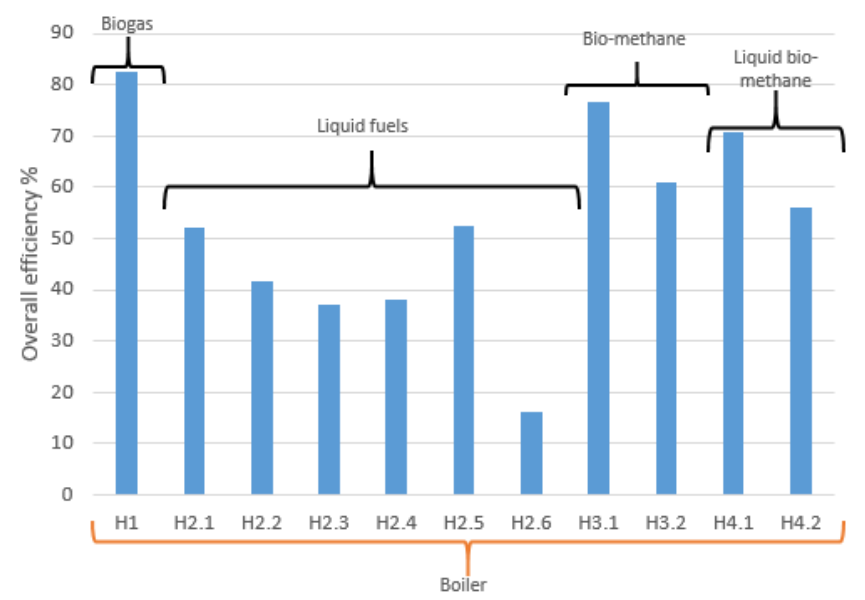


Fig 8: Routes' overall energy efficiencies for heat generation

\subsection{Electricity and heat generation}

Cogeneration has received much attention due to its ability to produce two useful products, heat (up to $180^{\circ} \mathrm{C}$ ) and electricity, with minimal losses [11]. A CHP unit's efficiency is classified as $90 \%$ (40\% electrical and $50 \%$ thermal), if the heat generated in the process was supplied to an appropriately matched heat demand [47]. The efficiencies of routes involving CHP (EH2, EH4.7-4.12, EH5.1-5.2, EH6.1-6.2, Fig 9) were reevaluated assuming full use of both the heat and electricity. Values varied between $15 \%$ and $90 \%$ (Fig 10). The use of raw biogas in a CHP unit boosted efficiency to $90 \%$ (route EH2) from $40 \%$ for electricity only. Transforming biogas to liquid fuels via FT synthesis showed promising results with values reaching $57 \%$ (route EH4.11) compared to $25 \%$ when not using the heat. Bio-methane used in a CHP (routes EH5.1-EH5.2) improved efficiency from 37\%, excluding the use of heat, to $84 \%$ when both the produced heat and electricity were used (route EH5.1). Bio-methane liquefaction showed similar results with the route's efficiency increasing from $34 \%$ for electricity utilization only to $77 \%$ for the use of both heat and electricity (route EH6.1).

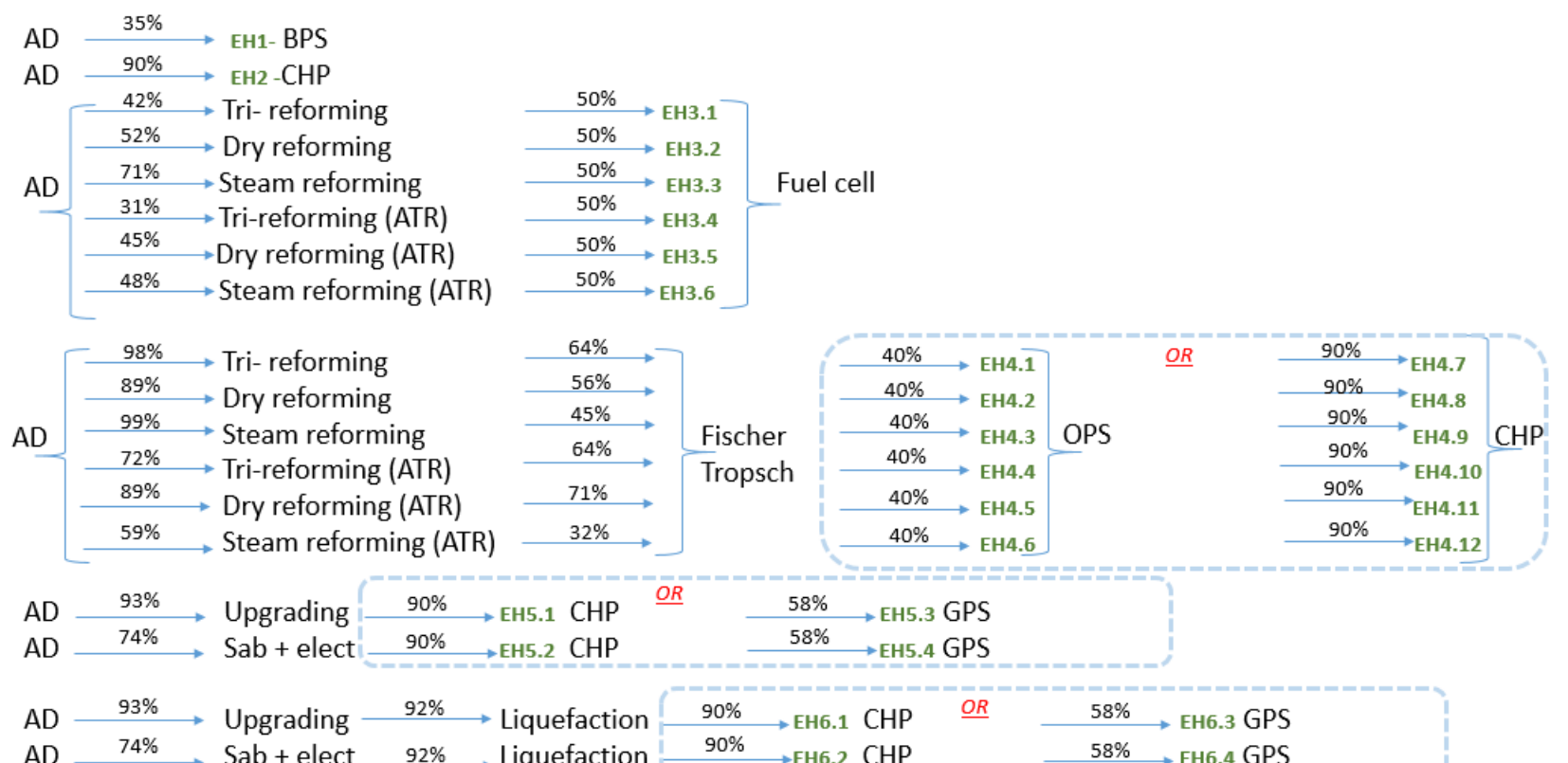


Fig 9: Component efficiency diagram for routes involved in electricity and heat generation

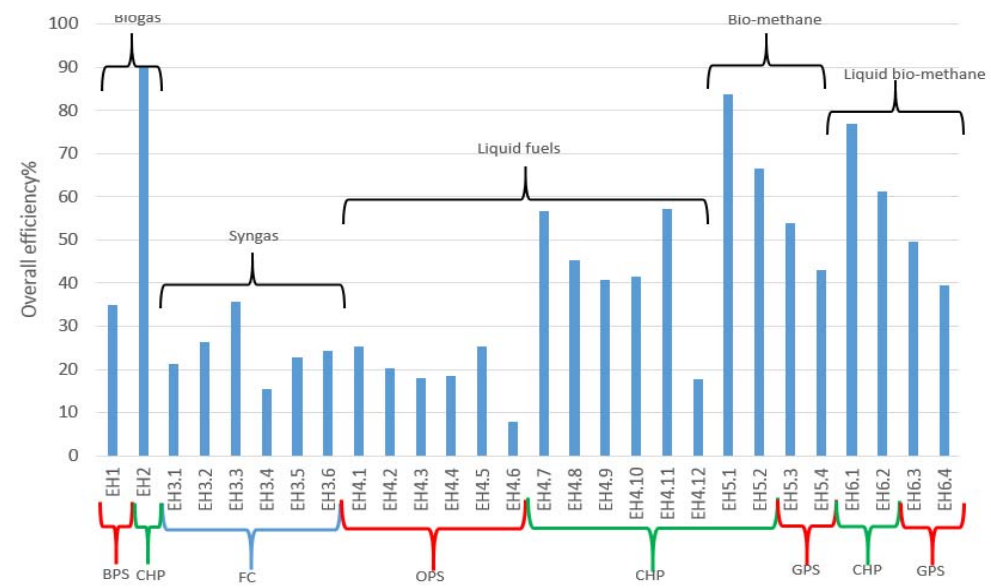

BPS: Biogas power station; ATR: Auto-thermal ; OPS: Oil power station; CHP: Combined heat and power; GPS: Gas power station Fig 10: Routes' overall energy efficiencies for electricity and heat generation

\subsection{Transport}

\subsubsection{ICE vehicles}

The routes leading to transport involved the production of intermediate fuels for use in ICE vehicles (Fig 11). For use of bio-methane, compression to CNG (routes T2.1-T2.2) or liquefaction to LNG (routes T2.3-T2.4) needs to be undertaken to enable sufficient fuel to be carried on the ICE vehicle. Compressed bio-methane used in an ICE (route T2.1) was the most efficient (18\%) of the transport routes (Fig 12), with an efficiency that was comparable to that of a gasoline-fueled vehicle. However, the result did not account for maintaining high pressure compression at 250 bar which requires energy input [48] that would decrease overall efficiency. LNG used in an ICE (route T2.3) reached an overall energy efficiency of $17 \%$, but constant chilling to $-161^{\circ} \mathrm{C}$ is needed which if considered would decrease efficiency. Liquid fuels via FT synthesis (routes T1.1-T1.6) showed lower efficiency values for transport (4-13\%), mainly due to energy demands of the reforming process.

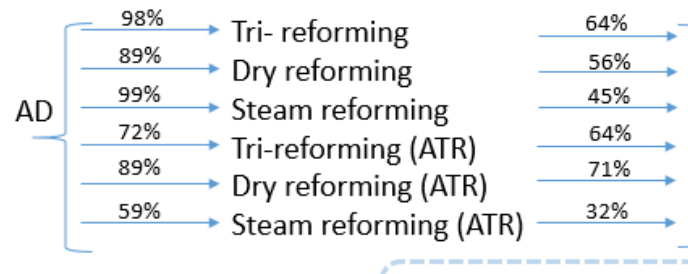

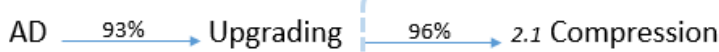

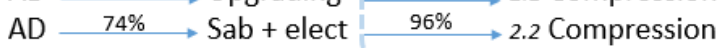

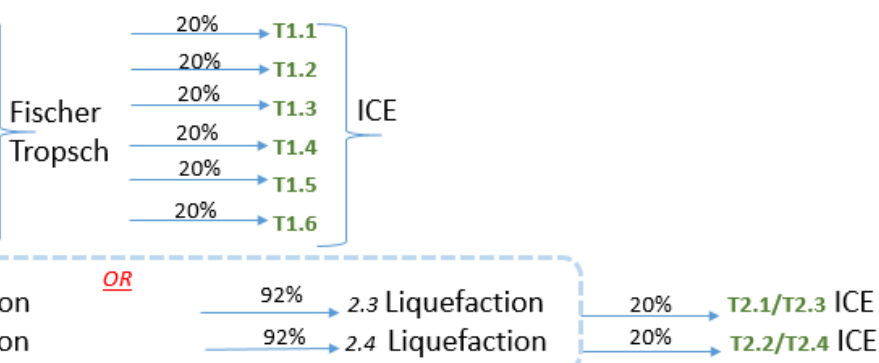




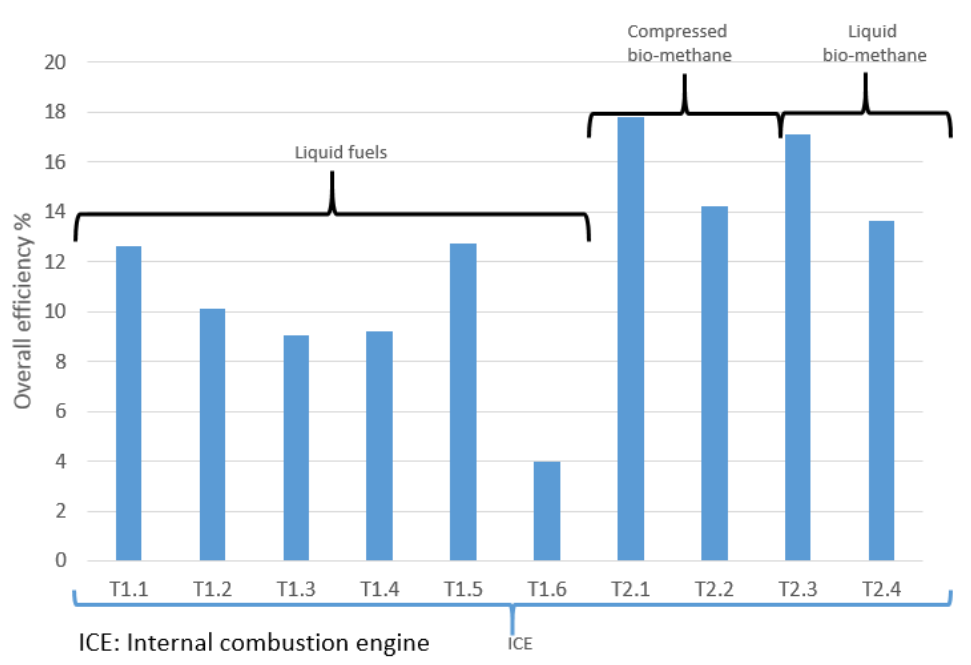

Fig 12: Routes' overall energy efficiencies for transportation

\subsubsection{Electric vehicles}

Theoretically, ICEs operate at a maximum of $30 \%$ efficiency, equivalent to $250 \mathrm{~g} / \mathrm{kWh}$ of gasoline fuel intake at a brake mean effective pressure (BMEP) of $700 \mathrm{kPa}$ and engine speed of 2000 rpm [49]. In reality, ICE vehicles fall behind design expectations irrespective of the type of fuel used, mainly because the engine rarely operates at its peak efficiency setting during normal driving patterns. Consequently, vehicle efficiency is typically around 20\% [50]. To achieve a more sustainable transport fleet, the European Commission and vehicle manufacturers have agreed to improve overall energy efficiency and to lower $\mathrm{CO}_{2}$ emissions in new vehicle sales by 2021 [51]. As a result, alternative vehicle technologies, such as electric vehicles, are under development in attempt to reduce oil dependency, avoid tail pipe emissions, decrease carbon emissions and increase energy efficiency [52].

Electric vehicles can convert 59\%-62\% of the electrical energy to mechanical energy (power to the wheels) giving them an average efficiency of $60.5 \%$ [53]. The overall efficiency of biogas to electric transport (Box 1) was calculated assuming electricity from a gas fired CCGT power plant. The calculation showed that even when including the efficiency of fuel production and electricity generation, electric vehicles still achieved almost 1.8 times the efficiency of standard ICE vehicles. This aligns with Kromer and Heywood [54], who stated that the overall efficiency (well-to-wheel) of electric vehicles could reach up to twice that of an ICE vehicle, given a high efficiency of electricity generation. Despite this, electric vehicles face significant challenges with regards to recharge time and driving range. Electric vehicles can reach a driving distance of $150 \mathrm{~km}$ when fully charged compared to 800 $\mathrm{km}$ or more for ICE vehicles filled with one tank of gasoline [52]. 
Box 1: Overall efficiency calculation of biogas to an electric vehicle

$$
\begin{aligned}
\eta(\text { overall })= & \eta(\text { biogas upgrading to bio }- \text { methane }) \times \eta(\text { natural gas power station }) \\
& \times \eta(\text { electric vehicle })=0.93 \times 0.58 \times 0.605=0.326 \sim 32.6 \%
\end{aligned}
$$

\section{Discussion}

\subsection{Importance of boundary conditions}

In summary, the route with fewer components generally leads to higher efficiencies since the route's overall efficiency follows a multiplicative sequential manner. Use as mechanical energy for transport, particularly, suffers due to the inherent inefficiencies of the internal combustion engine. Routes involving higher value liquid fuels (via FT synthesis) were typically relatively inefficient, although these options provide fuel flexibility in areas remote from the gas grid. Calculated efficiency values also showed that routes via CHP units were the optimum solution for biogas utilization. However, boundary expansion could have a significant impact on the results.

Overall efficiency values could drop if electricity sources for ancillary processes were considered within the study's boundary conditions; for example, for routes involving electrolysis the overall efficiency decreased by almost $40 \%$ when using a gas fired CCGT power plant at an efficiency of $58 \%$ as an electricity source (Figs 13-16). However, if a carbon neutral source such as wind was assumed, there was no impact on overall efficiency. Boundary conditions therefore need to be clearly stated and it is important that system boundaries are equivalent when comparing systems [20].

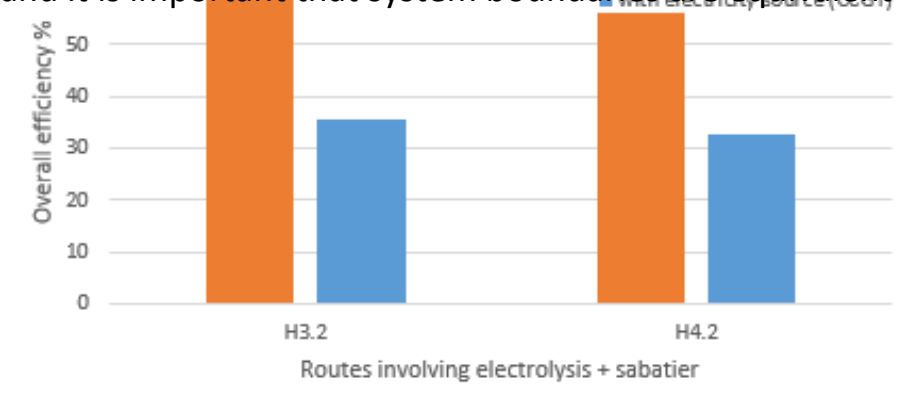

Fig 13: Electricity source effect on routes' overall energy efficiency for heat generation

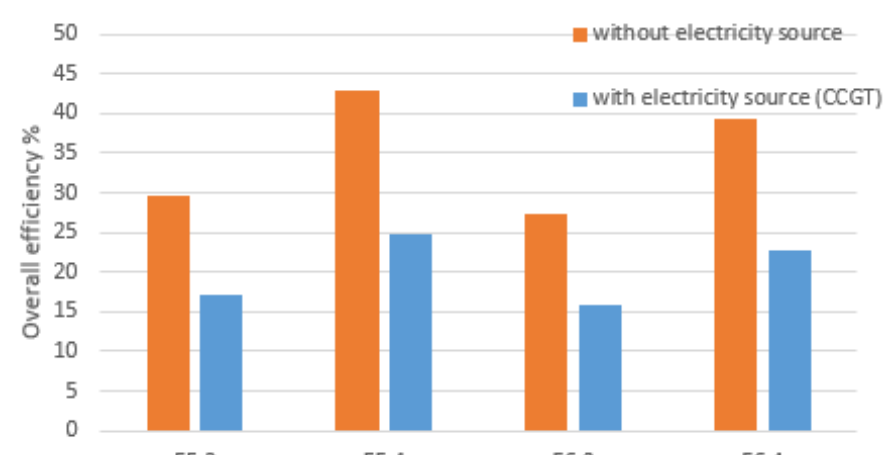


Fig 14: Electricity source effect on routes' overall energy efficiency for electricity generation

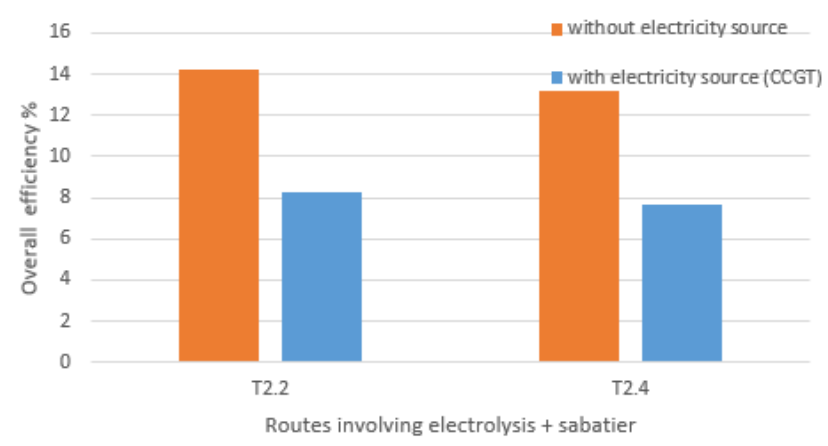

Fig 15: Electricity source effect on routes' overall energy efficiency for transportation

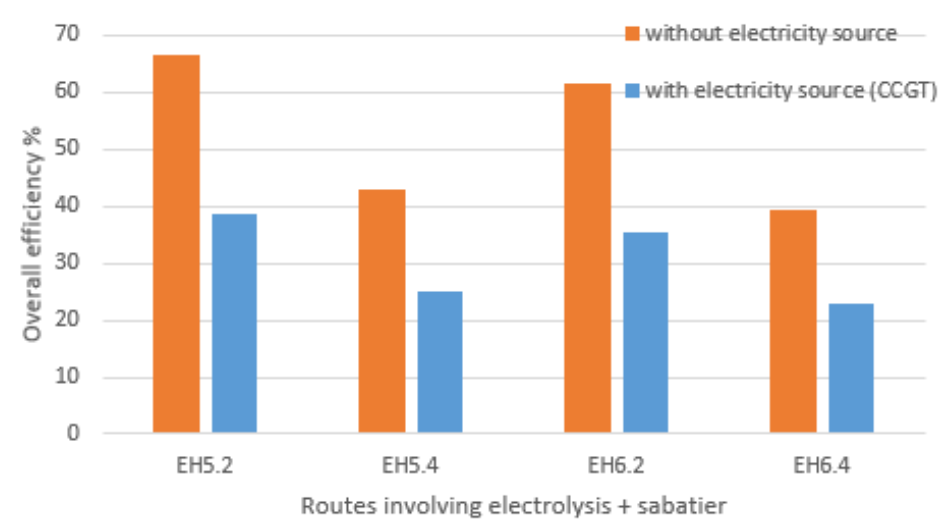

Fig 16: Electricity source effect on routes' overall energy efficiency for electricity and heat generation

\subsection{Comparison with fossil fuels}

Though many countries are already investing in renewable energy, fossil fuels are still industrialized society's most important fuel, accounting for $87 \%$ of global energy consumption [55]. It is therefore 
important to compare the energy efficiency of pathways for oil utilization to those for biogas. To enable direct comparison with the biogas analysis conducted in this paper (which excluded biogas production), the scope of the oil efficiency calculation was assumed to include refining and consumption while excluding extraction. Oil refining is analogous to biogas cleaning and upgrading. The energy required for biogas upgrading was taken into account in this paper, and, although the energy for biogas cleaning was not specifically included, many upgrading processes involve dual functionality and perform both the cleaning and upgrading steps, i.e. $\mathrm{CO}_{2}$ (upgrading) and $\mathrm{H}_{2} \mathrm{~S}$ (cleaning) removal. In the case of stand-alone cleaning methods, such as the biological techniques of precipitation, chemical absorption or adsorption on activated carbon, the processes are not energy intensive [56] and their exclusion from the calculation will not have a significant impact on the overall result. Unlike biogas cleaning, oil refining (cleaning) is not a biological process and requires energy intensive equipment as boilers, distillation columns and a Coker [57].

Han et al. [58] found that refining efficiencies varied between $88 \%$ and $95 \%$; an average value of $92 \%$ was considered for this analysis. Consumption was represented by a typical fuel oil power plant (Table 1). The overall route efficiency was $37 \%$ (Box 2), which competed well with many of the biogas routes. The comparatively high energy efficiency of oil utilization for energy, along with the fact that it is relatively inexpensive and easy to produce [55], strengthens its competitive advantage over renewables like biogas.

\section{Box 2: Overall efficiency calculation of oil usage}

$$
\eta(\text { overall })=\eta(\text { oil refining }) \times \eta(\text { consumption })=0.92 \times 0.4=0.368 \sim 37 \%
$$

The production stage was outside the boundary conditions for both the biogas and oil analyses. However, for biogas, it is widely agreed that the efficiency of the production stage (i.e. the anaerobic digestion facility) is increasing over time [59-61]. Conversely, in the case of oil, production in similar or lower amounts over time will require more energy. The efficiency of oil production is measured in terms of Energy Return on Investment (EROI). In 1919, the EROI was 1229:1, which corresponds to 1229 barrels produced for each barrel of oil used in the extraction process; in 2007, the value dropped to $10: 1$, implying that fossil fuel extraction has become more challenging and energy intensive [62]. The energy needed to produce 39,000 PJ of oil increased by 1,106 PJ between 1992 and 2007 [62], and this downward trend is likely to continue, strengthening the competitive advantage of biogas over oil. 


\subsection{Policy framework supporting biogas utilization}

While many countries have existing biogas industries, these industries vary both in scale of energy capacity and in pathways for biogas utilization. Political support and financial systems, such as investment grants, feed-in tariffs and tax exemptions, differ between countries, affecting the pathway of biogas utilization. The annual energy production from biogas varies between countries, for example, from as high as 42 TWh in Germany to as low as 0.6 TWh in Finland and Brazil; in most of these countries, biogas is mainly used for heat and electricity cogeneration [7]. The upgrading of biogas to bio-methane for use in transport has not received the same attention as liquid biofuels. Sweden is the only country with an established widespread market for bio-methane driven cars [45], although other countries, such as Denmark and Germany, show interest in increasing the share of biogas used as vehicle fuels [7]. However, despite interest in diversifying the industry away from just heat and power, there are limited comparative studies in the literature to aid decision makers in selecting the optimum route. As outlined in the literature review, previous research reported efficiencies of various routes but assumed different boundary conditions and end uses.

As shown in this paper, the choice of boundary conditions directly affects the results, making it difficult to compare consistently between different studies. Also, it is important to highlight the link between efficiency and resource utilization. In other words, a longer route might be less efficient but might also present potential for the incorporation of renewable sources, such as wind and solar energy, for fuelling ancillary processes like the Sabatier to bio-methane route. In addition, seemingly unfavourable routes, such as Fischer Tropsch liquid fuels for heat generation, might provide fuel flexibility, an option that is urgently needed in areas remote from the gas grid. By designing and analysing a consistent framework of 49 biogas utilization routes, this paper provides a solid scientific data on the energy efficiency of biogas utilization and highlights improvement potential in routes which have been overlooked.

Energy efficiency is not, however, the only factor in decision making. As discussed by Wu et al. [18], problems can arise when only one or two indices (environmental, economic or energetic) are assessed when evaluating biogas exploitation routes. Furthermore, ignoring political and societal conditions in any research leads to unrealistic conclusions [63]. Environmental constraints, economics, logistics, infrastructure and politics are other key factors in policy decision making. Despite the wide evidence base required to support policy decisions, Banister and Hickman [64] state that there is a gap between actual policy implementation and scenario-based research. Using the analytical framework developed in this paper to ensure comparable results, further research is required into environmental, economic and other factors to complement the energy efficiency analysis and provide a comprehensive multiindicator evidence base to support policy makers. 


\section{Conclusion}

This paper described the process of developing a solid scientific framework for the utilization of biogas combining a total of 49 possible pathways grouped into different final useful forms of energy. The framework was developed by adapting the LCA methodology to focus on "\% energy efficiency" as the functional unit. The boundaries were defined as beginning with clean biogas, at $60 \% \mathrm{CH}_{4}$ and $40 \% \mathrm{CO}_{2}$, which was then used in its raw or upgraded form to ultimately serve a final useful form of energy, which were grouped into three categories (i) electricity (ii) heat (iii) mechanical energy for transport. Along with the numerical results, the main transferrable output of this paper was the creation of an adaptable framework that ensures direct comparison amongst different routes, which were examined within consistent boundary conditions up to the final useful form of energy.

Energy efficiencies varied between $8 \%$ and $54 \%$ for electricity generation, $16 \%$ and $83 \%$ for heat, $18 \%$ and $90 \%$ for electricity and heat, and $4 \%$ and $18 \%$ for transport. Although the results showed that routes via CHP units were the optimum solution for biogas utilization, there are different ways in which the energy system responds to the requirements of sustainability. An energy strategy focusing on energy efficiency is essential as it tackles an overall system-comparison-analysis as opposed to an individual-component-analysis (which is location and feedstock dependent). This work represents an engineering system analysis of the overall biogas utilization system. The paper lays out all of the route options and compares them on a consistent basis while highlighting areas with room for improvement that are worthy of further investigation. Such areas include liquid fuel production, ICE technical improvement, and the use of other renewable sources, such as wind electricity for ancillary processes. The research also demonstrated that poor performance is mainly attributed to underutilized heat outputs. It is important to adapt a globalized view when it comes to sustainability; it would not have been possible to compare numerous routes and identify opportunities for process improvement prior to the development of this framework.

Optimization opportunities become available once different units are matched together. Thus, this study presents an important building block which can then be used to focus on a specific route that might become of interest. When a route is identified, it can be investigated further with expanded boundary conditions. Energy efficiency is not, however, the sole basis on which energy investments are or should be made. It is recommended that interdisciplinary research is conducted to complement on the energy efficiency work at a system level and to build a full baseline model that incorporates not just energy, but also environmental, technological and socio-economic issues. The research conducted for this paper provides the basis for an adaptable framework that can aid industrial and policy decision makers in developing a market to achieve renewable energy targets in a sustainable 
manner. The scientific framework of 49 interlinked routes is versatile and can be applied to criteria beyond energy efficiency involving economics, environmental, technical and social aspects. Sustainable development must be addressed in a globalized context as limitations remain unclear until they are touched upon.

\section{Acknowledgements}

This work was completed as part of the ATBEST (Advanced Technologies for Biogas Efficiency, Sustainability and Transport) Marie-Curie Initial Training Network. The network has received funding from the European Union's Seventh Framework Programme for research, technological development and demonstration under grant agreement n. 316838. ATBEST is coordinated by the QUESTOR Centre at Queen's University Belfast (www.atbest.eu).

\section{References}

[1] EUR-Lex. Access to European Union Law. 2009. [Online]. Available: http://eurlex.europa.eu/legal-content/EN/TXT/?uri=URISERV\%3Aen0009. [Accessed 31-06-2016].

[2] Abdeshahian, P., et al., Potential of biogas production from farm animal waste in Malaysia. Renewable and Sustainable Energy Reviews, 2016. 60: p. 714-723.

[3] Leonzio, G., Process analysis of biological Sabatier reaction for bio-methane production. Chemical Engineering Journal, 2016. 290: p. 490-498.

[4] Budzianowski, W.M., A review of potential innovations for production, conditioning and utilization of biogas with multiple-criteria assessment. Renewable and Sustainable Energy Reviews, 2016. 54: p. 1148-1171.

[5] Jahangiri, H., et al., A review of advanced catalyst development for Fischer-Tropsch synthesis of hydrocarbons from biomass derived syn-gas. Catalysis Science \& Technology, 2014. 4(8): p. 2210-2229.

[6] Gonzalez-Salazar, M.A., et al., Development of a technology roadmap for bioenergy exploitation including biofuels, waste-to-energy and power generation \&amp; CHP. Applied Energy, 2016. 180: p. 338-352.

[7] Persson, T. and D. Baxter, IEA Bioenergy Task 37 - Country Reports Summary 2014. 2014: United Kingdom.

[8] Fallde, M. and M. Eklund, Towards a sustainable socio-technical system of biogas for transport: the case of the city of Linköping in Sweden. Journal of Cleaner Production, 2015. 98: p. 17-28.

[9] Patrizio, P., et al., Biomethane as transport fuel - A comparison with other biogas utilization pathways in northern Italy. Applied Energy, 2015. 157: p. 25-34.

[10] Olsson, L., et al., Bridging the implementation gap: Combining backcasting and policy analysis to study renewable energy in urban road transport. Transport Policy, 2015. 37: p. 72-82.

[11] Pöschl, M., S. Ward, and P. Owende, Evaluation of energy efficiency of various biogas production and utilization pathways. Applied Energy, 2010. 87(11): p. 3305-3321.

[12] Chen, X., et al., Energy-efficient biogas reforming process to produce syngas: The enhanced methane conversion by O2. Applied Energy, 2017. 185, Part 1: p. 687-697. 
[13] Friesenhan, C., et al., Streamlined life cycle analysis for assessing energy and exergy performance as well as impact on the climate for landfill gas utilization technologies. Applied Energy, 2017. 185, Part 1: p. 805-813.

[14] Djatkov, D., M. Effenberger, and M. Martinov, Method for assessing and improving the efficiency of agricultural biogas plants based on fuzzy logic and expert systems. Applied Energy, 2014. 134: p. 163-175.

[15] Goulding, D. and N. Power, Which is the preferable biogas utilisation technology for anaerobic digestion of agricultural crops in Ireland: Biogas to CHP or biomethane as a transport fuel? Renewable Energy, 2013. 53: p. 121-131.

[16] Börjesson, P. and M. Berglund, Environmental systems analysis of biogas systems-Part I: Fuel-cycle emissions. Biomass and Bioenergy, 2006. 30(5): p. 469-485.

[17] Morero, B., E. Groppelli, and E.A. Campanella, Life cycle assessment of biomethane use in Argentina. Bioresource Technology, 2015. 182: p. 208-216.

[18] Wu, B., et al., Energetic-environmental-economic assessment of the biogas system with three utilization pathways: Combined heat and power, biomethane and fuel cell. Bioresource Technology, 2016. 214: p. 722-728.

[19] McKone, T.E., et al., Grand Challenges for Life-Cycle Assessment of Biofuels. Environmental Science \& Technology, 2011. 45(5): p. 1751-1756.

[20] Czyrnek-Delêtre, M.M., B.M. Smyth, and J.D. Murphy, Beyond carbon and energy: The challenge in setting guidelines for life cycle assessment of biofuel systems. Renewable Energy, 2017. 105: p. 436-448.

[21] Trianni, A., E. Cagno, and S. Farné, Barriers, drivers and decision-making process for industrial energy efficiency: A broad study among manufacturing small and medium-sized enterprises. Applied Energy, 2016. 162: p. 1537-1551.

[22] Hammond, G.P., Engineering sustainability: thermodynamics, energy systems, and the environment. International Journal of Energy Research, 2004. 28(7): p. 613-639.

[23] US Environmental Protection Agency, Life Cycle Assessment: Principles and Practice. 2006.

[24] Smyth, B.M., J.D. Murphy, and C.M. O'Brien, What is the energy balance of grass biomethane in Ireland and other temperate northern European climates? Renewable and Sustainable Energy Reviews, 2009. 13(9): p. 2349-2360.

[25] Department for Business Energy \& Industrial Strategy, Greenhouse gas reporting Conversion factors 2016. 2016. [Online]. Available:

https://www.gov.uk/government/publications/greenhouse-gas-reporting-conversionfactors-2016 [Accessed 13-04-16]

[26] Wang, D., et al., Life cycle analysis of internal combustion engine, electric and fuel cell vehicles for China. Energy, 2013. 59: p. 402-412.

[27] US Environmental Protection Agency, CHP Benefits. Agency, Editor. 2015. [Online]. Available: https://www.epa.gov/chp/chp-benefits/ [Accessed 30-07-2016].

[28] US Environmental Protection Agency, Efficiency Metrics for CHP Systems: Total System and Effective Electric Efficiencies. Agency, Editor. 2015. [Online]. Available:

https://www.arb.ca.gov/cc/ccei/presentations/chpefficiencymetrics_epa.pdf/ [Accessed 0108-2016]

[29] Clarke Energy. CHP efficiency for biogas. 2013. [Online]. Available: www.clarkeenergy.com/2013/chp-cogen-efficiency-biogas/ [Accessed 10-11-2016]

[30] Lems, R. and E. Dirkse Making pressurized water scrubbing the ultimate biogas upgrading technology with the DMT Carborex ${ }^{\circledR}$ PWS system. 2009. [Online]. Available:

http://www.environmental-expert.com/articles/making-pressurized-water-scrubbing-theultimate-biogas-upgrading-technology-with-the-dmt-carborex-pw-227999 [Accessed 03-092015]. 
[31] Frost, P. and S. Gilkinson, First 18 Month Performance Summary For Anaerobic Digestion of Dairy Cow Slurry at AFBI Hillsborough. 2010. [Online]. Available: http://docplayer.net/14934443-Interim-technical-report-first-18-month-performancesummary-for-anaerobic-digestion-of-dairy-cow-slurry-at-afbi-hillsborough.html [Accessed 28-07-2016].

[32] Bartaire, J.G., et al., Efficiency in Electricity Generation. 2003, VGB, Eurelectric-Union of the Electricity Industry: Brussels, Essen. p. 30.

[33] Johansson, N., Production of liquid biogas, LBG, with cryogenic and conventional upgrading technology, in Department of Technology and Society. Master Thesis. 2008, Lund University: Lund- Sweden. p. 92.

[34] US National Renewable Energy Laboratory, Technology Brief: Analysis of Current-Day Commercial Electrolyzers, Energy, Editor. 2004, NREL: Colorado. [Online]. Available: http://www.nrel.gov/docs/fy04osti/36705.pdf/ [Accessed 01-12-2015]

[35] Ralston, J. The Sabatier Reaction, Possible Solution to $\mathrm{CO}_{2}$ Emissions. 2010. [Online]. . Available: http://www.pennenergy.com/articles/pennenergy/2010/03/the-sabatierreaction.html [Accessed 03-09-2015].

[36] Wang, T., et al., Auto-thermal reforming of biomass raw fuel gas to syngas in a novel reformer: Promotion of hot-electron. Applied Energy, 2013. 112: p. 448-453.

[37] Han, G., S. Lee, and J. Bae, Diesel autothermal reforming with hydrogen peroxide for lowoxygen environments. Applied Energy, 2015. 156: p. 99-106.

[38] Aspen Technology. Design and Optimize Chemical Processes with Aspen Plus ${ }^{\circledast}$. [Online]. Aspentech. Available: http://www.aspentech.com/products/aspen-plus.aspx [Accessed 2007-2016].

[39] Iulianelli, A., et al., Advances on methane steam reforming to produce hydrogen through membrane reactors technology: A review. Catalysis Reviews, 2016. 58(1): p. 1-35.

[40] Ghoneim, S.A., R.A. El-Salamony, and S.A. El-Temtamy, Review on Innovative Catalytic Reforming of Natural Gas to Syngas. World Journal of Engineering and Technology, 2016.

[41] Maitlis, P.M., in Greener Fischer Tropsch Processes for Fuels and Feedstocks, P.M. Maitlis and A. de Klerk, Editors. 2013, Wiley-VCH.

[42] Ashraf, M.T., J.-R. Bastidas-Oyanedel, and A. Schmidt, Conversion Efficiency of Biogas to Liquids Fuels through Fischer-Tropsch Process. 2015. 23rd European Biomass Conference and Exhibition. Vienna, Austria [01-06-2015 to 04-06-2015]. [Online]. Available: http://www.etaflorence.it/proceedings/?detail=11205 [Accessed 03-08-2015]

[43] Revina, D. Investment projects syngas by gasification of coal. Attracting investment in advanced fossil fuel technologies. 2012. [Online]. Available:

http://www.unece.org/fileadmin/DAM/energy/se/pp/clep/IntIncConf_Nov2012_Alamty/10s 7_Revina.pdf. [Accessed 30-07-2017]

[44] US Department of Energy, Fuel Properties Comparison. 2015. [Online]. Available: http://www.afdc.energy.gov/fuels/fuel_properties.php/ [Accessed 30-07-2016].

[45] Svensson, M., 18 - Biomethane for transport applications A2 - Wellinger, Arthur, in The Biogas Handbook, J. Murphy and D. Baxter, Editors. 2013, Woodhead Publishing. p. 428-443.

[46] DiGenova, K.J., et al., Fischer Tropsch reactor with integrated organic rankine cycle. 2014, Patent number: US 20130090395 A1.

[47] Department of Energy \& Climate Change, Climate change and energy-guidance. Change, Editor. 2013. [Online]. Available: https://www.gov.uk/guidance/combined-heat-and-power/ [Accessed 01 June 2016]. 
[48] Bates, J., Biomethane for Transport from Landfill and Anaerobic Digestion, D.f. Transport, Editor. 2015: Oxfordshire United Kingdom. p. 66. [Online]. Available:

https://www.gov.uk/government/uploads/system/uploads/attachment_data/file/416002/bi omethane-for-transport.pdf [Accessed 06-01-2017].

[49] Heywood, J.B., Internal Combustion engine Fundamentals. 1988: McGraw-Hill. 930.

[50] Department of Energy \& Climate Change, Multi-million pound fund to get hydrogen cars moving. UK: Industrial strategy and Low carbon technologies. 2014. [Online]. Available: https://www.gov.uk/government/news/multi-million-pound-fund-to-get-hydrogen-carsmoving / [Accessed 27 September 2016].

[51] Duarte, G., C. Rolim, and P. Baptista, How battery electric vehicles can contribute to sustainable urban logistics: A real-world application in Lisbon, Portugal. Sustainable Energy Technologies and Assessments, 2016. 15: p. 71-78.

[52] Asamer, J., et al., Sensitivity analysis for energy demand estimation of electric vehicles. Transportation Research Part D: Transport and Environment, 2016. 46: p. 182-199.

[53] US Department of Energy, All-Electric Vehicles. Energy, Editor. 2016. [Online]. Available: https://www.fueleconomy.gov/feg/evtech.shtml/ [Accessed 01-07-2016].

[54] Kromer, M.A. and J.B. Heywood, Electric Powertrains: Opportunities and Challenges in the U.S. Light-Duty Vehicle Fleet. 2007, Sloan Automotive Laboratory, Laboratory for Energy and the Environment: 77 Massachusetts Avenue,Cambridge, MA 02139.

[55] Biresselioglu, M.E. and T. Yelkenci, Scrutinizing the causality relationships between prices, production and consumption of fossil fuels: A panel data approach. Energy, 2016. 102: p. 4453.

[56] Petersson, A. and A. Wellinger, Biogas upgrading technologies -developments and innovations. Task 37 - Energy from biogas and landfill gas- IEA Bioenergy, 2009.

[57] Clews, R.J., Chapter 7 - Petroleum Refining, in Project Finance for the International Petroleum Industry. 2016, Academic Press: San Diego. p. 119-136.

[58] Han, J., et al., A comparative assessment of resource efficiency in petroleum refining. Fuel, 2015. 157: p. 292-298.

[59] Jin, Y., Y. Li, and J. Li, Influence of thermal pretreatment on physical and chemical properties of kitchen waste and the efficiency of anaerobic digestion. Journal of Environmental Management, 2016. 180: p. 291-300.

[60] Suanon, F., et al., Application of nanoscale zero valent iron and iron powder during sludge anaerobic digestion: Impact on methane yield and pharmaceutical and personal care products degradation. Journal of Hazardous Materials, 2017. 321: p. 47-53.

[61] Zhen, G., et al., Overview of pretreatment strategies for enhancing sewage sludge disintegration and subsequent anaerobic digestion: Current advances, full-scale application and future perspectives. Renewable and Sustainable Energy Reviews, 2017. 69: p. 559-577.

[62] Guilford, M.C., et al., A New Long Term Assessment of Energy Return on Investment (EROI) for U.S. Oil and Gas Discovery and Production. Sustainability, 2011. 3(10): p. 1866.

[63] Nilsson, M., et al., The missing link: Bringing institutions and politics into energy future studies. Futures, 2011. 43(10): p. 1117-1128.

[64] Hickman, R., P. Hall, and D. Banister, Planning more for sustainable mobility. Journal of Transport Geography, 2013. 33: p. 210-219. 


\section{Supplementary Data}

\section{A: Simulations and FT calculations}

\section{-A1. Overview of reforming and FT analysis}

When calculating the efficiency of the reforming techniques, equation A1.1 was used. The equation relates the output material $\left(\mathrm{CO}\right.$ and $\left.\mathrm{H}_{2}\right)$ to the input material $\left(\mathrm{CH}_{4}\right.$ and/or $\left.\mathrm{CO}_{2}\right)$ based on their molar flow rates and LHV values (Table A1.1).

$\eta_{x}=\frac{\text { Energy }_{\text {out }}(J)}{\text { Energy }_{\text {in }}(J)}=\frac{\sum L H V_{\text {out }, a} m_{\text {out }, a}}{\sum L H V_{\text {in }, b} m_{\text {in }, b}+Q_{\text {supplied }}} \times 100$

Where:

- $\mathrm{LHV}_{\text {out/in }}$ : lower heating value of the input (b) or output (a) material $\left(\mathrm{Jmol}^{-1}\right)$

- $\mathrm{m}_{\text {out} / \text { in: }}$ molar flow rate of input (a) or output (b) material $\left(\mathrm{mols}^{-1}\right)$

- $\mathrm{Q}_{\text {supplied: }}$ power supplied $\left(\mathrm{Js}^{-1}\right)$

Table A1.1: LHV values of material input/output

\begin{tabular}{l|l} 
Material & LHV $\left(\mathrm{Jmol}^{-1}\right)$ \\
\hline $\mathrm{CH}_{4}$ & $8.03 \mathrm{E}+08$ \\
$\mathrm{H}_{2}$ & $2.42 \mathrm{E}+08$ \\
$\mathrm{CO}$ & $2.83 \mathrm{E}+08$
\end{tabular}

The heat exchanger used to heat the input material from room temperature $25^{\circ} \mathrm{C}$ to $800^{\circ} \mathrm{C}$ was a heater block (referred to as $\mathrm{Hx}$ in Aspen); the power of the heater block is included in equation A1.1 as part of $Q_{\text {supplied. }}$. For the base unit, 1 mols $^{-1}$ of biogas was assumed to be composed of $60 \% \mathrm{CH}_{4}$ and $40 \% \mathrm{CO}_{2}$. Whenever $\mathrm{CO}_{2}$ was not needed (in the case of steam reforming), $0.6 \mathrm{mols}^{-1}$ of $\mathrm{CH}_{4}$ was assumed as the base unit. Also, the temperature of the output stream was assumed to be the same as the temperature of the reactor $\left(800^{\circ} \mathrm{C}\right)$. The high temperature output stream $\left(800^{\circ} \mathrm{C}\right)$ required cooling before going into the low temperature FT synthesis at $250^{\circ} \mathrm{C}$; heat integration between these two is therefore possible, but for the purpose of this paper, heat integration was omitted in all scenarios. The reasons for excluding heat integration were: (i) to ensure the results of all routes were comparable, and (ii) even if it were included, it would not boost the energy efficiency significantly (an example calculation is presented in section $\mathrm{A} 3$ ).

FT synthesis is a very complex reaction that requires specific data to be simulated in series with reforming. As the aim of the paper was to provide a framework of efficiencies that was flexible and could provide a basis for further calculations and optimization, it was important to handle the process from a more generalized viewpoint. The power supplied ( $\left.Q_{\text {supplied }}\right)$ was assumed to be due to 
compression to 20 bar [1]. Ashraf et al. [2] simulated the FT process at standard operating conditions (20 bar and $250^{\circ} \mathrm{C}$ ) and found that the power needed to compress $1 \mathrm{mols}^{-1}$ of syngas was $22,636.64$ $\mathrm{Jmol}^{-1}$. The Q supplied was then calculated by multiplying this value by the syngas molar flow obtained from the reforming simulations output (datasets are contained in sections A2-A7).

The efficiency calculations were based on $33 \%$ weight of the total outputs, which represents the liquid fraction $\left(\mathrm{C}_{5}-\mathrm{C}_{22}\right)$ of the total FT output for cobalt-based low temperature FT [3] that can be used directly for electricity, heat and transport; this portion excludes the lights and wax products produced at standard conditions (thus hydrocracking was not needed). Also, LHV values (equivalent to heat of combustion) were calculated twice: once as the average value of $\mathrm{C}_{5}-\mathrm{C}_{10}$ individual $\mathrm{LHV}$ values and the second time as the average value of $\mathrm{C}_{11}-\mathrm{C}_{22}$ individual LHV values [4]. Without full experimental testing and associated in-depth simulation, the exact amount of each fraction produced within the $C_{5}-C_{22}$ range cannot be accurately determined. The exclusion of this data does not affect the overall conclusions of this study as FT already showed uncompetitive efficiency values that would only decrease further if distillation was taken into account.

\section{A2. Dry reforming simulation datasets}

The dry reforming process was simulated on Aspen (Fig A2.1); more details on operating and feed conditions can be found in Table A2.1. Dry reforming and FT results along with FT efficiency calculations are presented in Table A2.2.

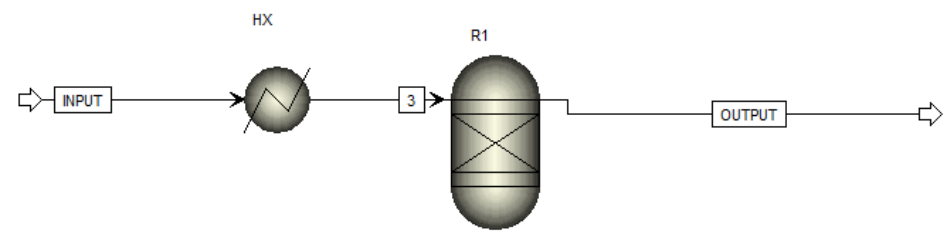

Fig A2.17: Dry reforming Aspen simulation

Table A2.1: Aspen assumptions for dry reforming

\begin{tabular}{llll}
\hline Stream & Explanation & Symbol & Explanation \\
\hline Input & $\mathrm{CH}_{4}$ and $\mathrm{CO}_{2}$ & $\mathrm{Hx}$ & Heater \\
\hline Output & $\mathrm{CO}$ and $\mathrm{H}_{2}$ & $\mathrm{R} 1$ & Gibbs reactor \\
\hline 3 & Heated $\mathrm{CH}_{4}$ and $\mathrm{CO}_{2}$ & \\
\hline & Assumptions \\
\hline Feed conditions & $\mathrm{CO}_{2} / \mathrm{CH}_{4}: \mathbf{2} / \mathbf{3}$ and 1 mols $^{-1}$ \\
\hline Feed temperature & $\mathbf{2 5 ^ { \circ } \mathrm { C }}$ \\
\hline Feed pressure & $\mathbf{1 ~ b a r}$ \\
\hline Process pressure & $\mathbf{1 ~ b a r}$ \\
\hline
\end{tabular}




\begin{tabular}{ll}
\hline Process temperature & $\mathbf{8 0 0} \mathbf{C}$ \\
\hline Equation of state & Peng Robinson \\
\hline Table A2.2: Dry reforming and FT results, and FT efficiency calculations
\end{tabular}

\section{Dry reforming}

\begin{tabular}{|c|c|c|c|c|c|c|c|c|c|c|}
\hline \multirow{2}{*}{$\begin{array}{c}\text { Temperature } \\
\left({ }^{\circ} \mathrm{C}\right) \\
798.27\end{array}$} & \multirow{2}{*}{$\frac{\text { Output }}{\text { CO }}$} & \multirow{2}{*}{$\frac{\mathrm{kmols}^{-1}}{0.000536}$} & $\mathrm{kgkmol}^{-1}$ & $\mathrm{kgs}^{-1}$ & \multicolumn{2}{|c|}{ LHV } & $\mathrm{mols}^{-1}$ & \multirow{2}{*}{$\frac{\mathrm{kJs}^{-1}}{151.75}$} & & \\
\hline & & & 28 & 0.015007 & MJkg $^{-1}$ & kJmol-1 & 0.54 & & & \\
\hline 89.49 & Sum & & & 0.017137 & 119.96 & 239.92 & 1.60 & 407.31 & & \\
\hline \multicolumn{11}{|c|}{ Fischer Tropsch } \\
\hline \multicolumn{9}{|c|}{$\begin{array}{c}\text { Average } \\
\text { molecular weight }\end{array}$} & \multicolumn{2}{|l|}{ LHV } \\
\hline$C_{5}-C_{10}$ & & 12.00 & & 002056 & \multicolumn{2}{|c|}{0.107217} & \multicolumn{2}{|c|}{0.019180} & 4774.63 & 91.58 \\
\hline $\mathrm{C}_{11}-\mathrm{C}_{22}$ & & 20.80 & & 003564 & \multicolumn{2}{|c|}{0.233459} & \multicolumn{2}{|c|}{0.015268} & 10382.02 & 158.51 \\
\hline Sum & & 32.80 & & - & & - & & - & - & 250.09 \\
\hline \multicolumn{11}{|c|}{ Efficiency Calculation } \\
\hline $\operatorname{Efficiency}(\eta x)=$ & $\frac{\text { Energy }_{\text {out }}}{\text { Energy }_{\text {in }}}$ & $\frac{(J)}{J)}=\frac{\sum l}{\sum L H V_{i}}$ & $\frac{V_{\text {out }, a} m_{\text {out }, a}}{m_{\text {in }, b}+Q_{\text {sup }}}$ & $\times 100=$ & \multicolumn{4}{|c|}{$\frac{250.09}{(407.31+36.22)} \times 100=56.38 \%$} & & \\
\hline
\end{tabular}

Sample calculations for FT efficiency analysis are presented in the following three steps; the same method was also applied for the $C_{11}-C_{22}$ fraction and then summed to give the total amount of liquid products produced via FT that could be used for energy production.

1. Mass flow rate of $C_{5}-C_{10}\left(\mathrm{kgs}^{-1}\right)=\left[\right.$ weight $(\%) \times$ total output mass flow rate $\left.\left(\mathrm{kgs}^{-1}\right)\right] / 100$

$$
=(12 \times 0.017137) / 100=0.002056
$$

2. Molar flow rate of $C_{5}-C_{10}\left(\right.$ mols $\left.^{-1}\right)=$ Mass flow rate of $C_{5}-C_{10}\left(\mathrm{kgs}^{-1}\right) /$ Average molecular weight $\left(\mathrm{kgmol}^{-1}\right)$

$$
=0.002056 / 0.107217=0.019180
$$

3. $L H V_{\text {out } \mathrm{C} 5-\mathrm{C} 10,} m_{\text {out },}, \dot{\mathrm{C}}_{5}-\mathrm{C} 10=$ Molar flow rate of $\mathrm{C}_{5}-\mathrm{C}_{10}\left(\mathrm{mols}^{-1}\right) \times \mathrm{LHV}\left(\mathrm{kJmol}^{-1}\right)$

$$
=0.019180 \times 4774.63=91.58
$$

\section{A3. Dry reforming (ATR) simulation datasets}

The auto-thermal dry reforming process was simulated on Aspen (Fig A3.1); more details on operating and feed conditions can be found in Table A3.1. Dry reforming and FT results along with FT efficiency calculations are presented in Table A3.2.

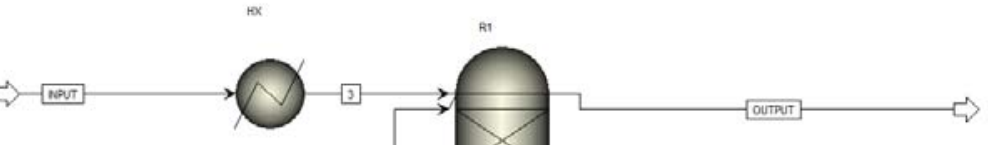


Fig A3.1: Dry reforming (ATR) Aspen simulation

Table A3.1: Aspen assumptions for dry reforming (ATR)

\begin{tabular}{llll}
\hline Stream & Explanation & Symbol & Explanation \\
\hline Input & Air, $\mathrm{CH}_{4}, \mathrm{CO}_{2}$ & $\mathrm{Hx}$ & Heater \\
\hline Output & $\mathrm{CO}$ and $\mathrm{H}_{2}$ & $\mathrm{R} 1$ & Gibbs reactor \\
\hline 3 & Heated $\mathrm{CH}_{4}$ and $\mathrm{CO}_{2}$ & \\
\hline & Assumptions & \\
\hline Feed conditions & $\mathrm{CO}_{2} / \mathrm{CH}_{4}: 2 / 3$ and $1 \mathrm{mols}^{-1}$ \\
\hline Feed temperature & $\mathbf{2 5 ^ { \circ } \mathrm { C }}$ \\
\hline Feed pressure & $\mathbf{1 ~ b a r}$ & \\
\hline Process pressure & $\mathbf{1 ~ b a r}$ \\
\hline Process temperature & $\mathbf{8 0 0} \mathrm{C}$ \\
\hline Equation of state & Peng Robinson \\
\hline
\end{tabular}

Table A3.2: Dry reforming (ATR) and FT results, and FT efficiency calculations

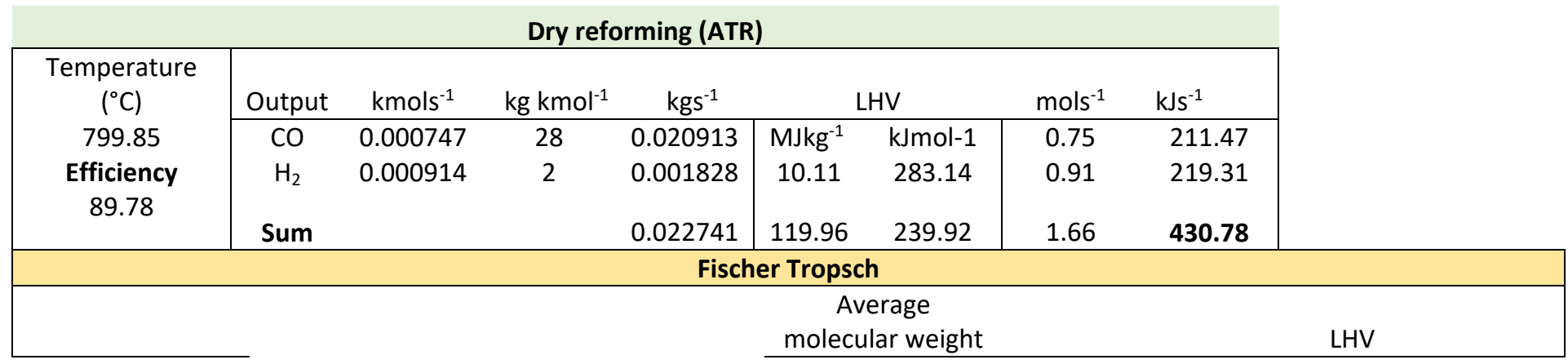




\begin{tabular}{|c|c|c|c|c|c|c|}
\hline Products & Weight \% & $\mathrm{kgs}^{-1}$ & $\mathrm{kgmol}^{-1}$ & $\mathrm{mols}^{-1}$ & $\mathrm{kJmol}^{-1}$ & $\mathrm{kJs}^{-1}$ \\
\hline$C_{5}-C_{10}$ & 12.00 & 0.002730 & 0.107217 & 0.025453 & 4774.63 & 121.53 \\
\hline $\mathrm{C}_{11}-\mathrm{C}_{22}$ & 20.80 & 0.004730 & 0.233458 & 0.020261 & 10382.02 & 210.35 \\
\hline Sum & 32.80 & - & - & - & - & 331.88 \\
\hline \multicolumn{7}{|c|}{ Efficiency Calculation } \\
\hline \multicolumn{7}{|c|}{$Q_{\text {supplied }} \mathrm{kW}=\frac{\text { Sum (syngas) } \mathrm{mols}^{-1} \times Q_{\text {supplied }} \mathrm{Jmol}^{-1}}{1000}=(1.66 \times 22636.64) / 1000=\mathbf{3 7 . 5 7}$} \\
\hline \multicolumn{3}{|c|}{ Efficiency $_{\left(\eta_{\mathrm{x}}\right)}=\frac{\text { Energy }_{\text {out }}(J)}{\text { Energy }_{\text {in }}(J)}=\frac{\sum L H V_{\text {out }, a} m_{\text {out }, a}}{\sum L H V_{\text {in }, b} m_{\text {in }, b}+Q_{\text {supplied }}}$} & \multicolumn{2}{|c|}{$\mathrm{x} 100=\frac{331.88}{(430.78+37.57)} \times 100=70.86 \%$} & & \\
\hline
\end{tabular}

An example of heat integration is presented (Box A3.1) to highlight the insignificant effect that Qsupplied $_{\text {. }}$ has on the overall efficiency when the term responsible for heating the feed is excluded (the change is $<0.01 \%)$. Thus, $Q_{\text {supplied }}$ only includes the energy supplied for the reactor while assuming that the feed is heated by the energy released from cooling the output stream from $800^{\circ} \mathrm{C}$ to $250^{\circ} \mathrm{C}$.

\section{Box A3.1: Heater effect on the calculation of $Q_{\text {supplied }}$}

Refer to Fig A3.1 for stream references and to Supplementary Data B (section B.1) for heat balances. Option 1 is calculated with the heater energy requirement and Option 2 excludes the heater energy requirement.

1. Qsupplied $(W)=$ Reactor $\mathbf{R} 1$ enegy input $(W)+$ Heater $\mathbf{H x}$ energy input $(W)=$ [Enthalpy of output stream (W) - Enthalpy of air stream $(W)$ -

Enthalpy of stream $3(W)]+[$ Enthalpy of stream $3(W)-$

Enthalpy of input stream $(Q)]==-160852.34+14.26+160838.52-160838.52+$ $202141.35=41,303.27=41.30 \mathrm{~kW}$

2. Qsupplied (W) = Reactor $\mathbf{R} 1$ enegy input $(W))=$ [Enthalpy of output stream (W) Enthalpy of air stream $(W)-$ Enthalpy of stream $3(W)]=-160852.34+14.26+$ $160838.52=0.42=0.000420 \mathrm{~kW}$

Re-calculating the reforming efficiency where the input material is $\mathrm{CO}$ and $\mathrm{H}_{2}$ while the output is $\mathrm{CH}_{4}$

1. $\eta \mathrm{x}(\%)=\frac{\text { Energy }_{\text {out }}(J)}{\text { Energy }_{\text {in }}(J)}=\frac{\sum L H V_{\text {out }, a} m_{\text {out }, a}}{\sum L H V_{\text {in, }, b} m_{\text {in, }}+Q_{\text {supplied }}} \quad \times 100=[433000 /(482000+41.30)] \times 100=$

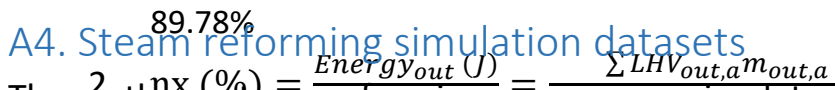

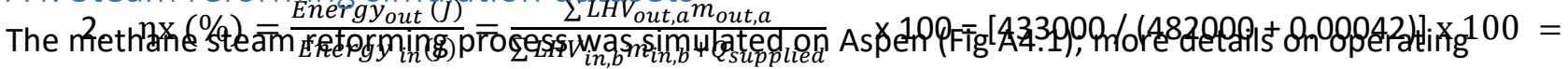
and feed $89.79 \%$ \%ions can be found in Table A4.1. Dry reforming and FT results along with FT efficiency

calculations are presented in Table A4.2.

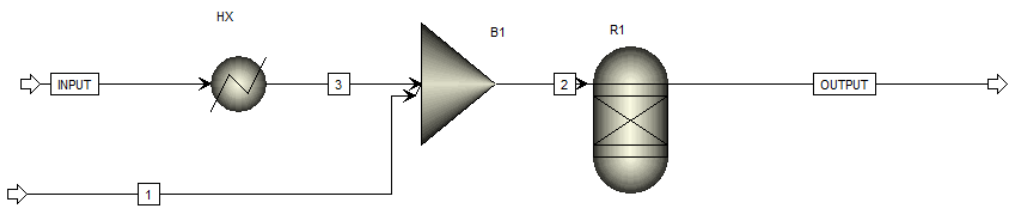

Fig A4.1: Steam reforming Aspen simulation

Table A4.1: Aspen assumptions for steam reforming

\begin{tabular}{llll}
\hline Stream & Explanation & Symbol & Explanation \\
\hline
\end{tabular}




\begin{tabular}{|c|c|c|c|}
\hline Input & $\mathrm{CH}_{4}$ and $\mathrm{H}_{2} \mathrm{O}$ & $\mathrm{Hx}$ & Heater \\
\hline Output & $\mathrm{CO}$ and $\mathrm{H}_{2}$ & B1 & Mixer \\
\hline 1 & $\mathrm{H}_{2} \mathrm{O}$ & R1 & Gibbs reactor \\
\hline 2 & \multicolumn{3}{|c|}{$\mathrm{H}_{2} \mathrm{O}, \mathrm{CH}_{4}$ and $\mathrm{CO}_{2}$} \\
\hline 3 & \multicolumn{3}{|l|}{ Heated $\mathrm{CH}_{4}$} \\
\hline \multicolumn{4}{|c|}{ Assumptions } \\
\hline \multicolumn{2}{|c|}{ Feed conditions } & \multicolumn{2}{|c|}{$\mathrm{H}_{2} \mathrm{O} / \mathrm{CH}_{4}: 3 / 1$ and $\mathrm{CH}_{4} 0.6 \mathrm{mols}^{-1}$} \\
\hline \multicolumn{2}{|c|}{ Feed temperature } & \multicolumn{2}{|c|}{$25^{\circ} \mathrm{C}$} \\
\hline \multicolumn{2}{|c|}{ Feed pressure } & \multicolumn{2}{|c|}{1 bar } \\
\hline \multicolumn{2}{|c|}{ Process pressure } & \multicolumn{2}{|c|}{1 bar } \\
\hline \multicolumn{2}{|c|}{ Process temperature } & \multicolumn{2}{|c|}{$800^{\circ} \mathrm{C}$} \\
\hline \multicolumn{2}{|c|}{ Equation of state } & \multicolumn{2}{|c|}{ Peng Robinson } \\
\hline
\end{tabular}

Table A4.2: Steam reforming and FT results, and FT efficiency calculations

Steam reforming

\begin{tabular}{|c|c|c|c|c|c|c|c|c|c|c|}
\hline \multicolumn{9}{|l|}{-7} & & \\
\hline $\begin{array}{c}\text { Temperature } \\
\left({ }^{\circ} \mathrm{C}\right)\end{array}$ & Output & $\mathrm{kmols}^{-1}$ & $\mathrm{kgkmol}^{-1}$ & $\mathrm{kgs}^{-1}$ & \multicolumn{2}{|c|}{ LHV } & \multirow{2}{*}{$\frac{\mathrm{mols}^{-1}}{0.59}$} & \multirow{2}{*}{$\frac{\mathrm{kJs}^{-1}}{168.98}$} & & \\
\hline 798.27 & $\mathrm{CO}$ & 0.000597 & 28 & 0.016710 & $\mathrm{MJkg}^{-1}$ & kJmol-1 & & & & \\
\hline Efficiency & $\mathrm{H}_{2}$ & 0.001791 & 2 & 0.003581 & 10.11 & 283.14 & 1.79 & 429.57 & & \\
\hline 89.86 & Sum & & & 0.020292 & 119.96 & 239.92 & 2.38 & 598.55 & & \\
\hline \multicolumn{11}{|c|}{ Fischer Tropsch } \\
\hline \multicolumn{11}{|c|}{$\begin{array}{c}\text { Average } \\
\text { molecular weight }\end{array}$} \\
\hline Products & & Weight \% & & $\mathrm{kgs}^{-1}$ & \multicolumn{2}{|c|}{$\mathrm{kgmol}^{-1}$} & \multicolumn{2}{|c|}{$\mathrm{mols}^{-1}$} & $\mathrm{kJmol}^{-1}$ & $\mathrm{kJs}^{-1}$ \\
\hline$C_{5}-C_{10}$ & & 12.00 & & 0.002435 & \multicolumn{2}{|c|}{0.107217} & \multicolumn{2}{|c|}{0.018079} & 4774.63 & 108.44 \\
\hline $\mathrm{C}_{11}-\mathrm{C}_{22}$ & & 20.80 & & 0.004221 & \multicolumn{2}{|c|}{0.233458} & \multicolumn{2}{|c|}{0.024216} & 10382.02 & 187.69 \\
\hline Sum & & 32.80 & & - & \multicolumn{2}{|c|}{-} & \multicolumn{2}{|c|}{-} & - & 296.13 \\
\hline \multicolumn{11}{|c|}{ Efficiency Calculation } \\
\hline \multicolumn{11}{|c|}{ 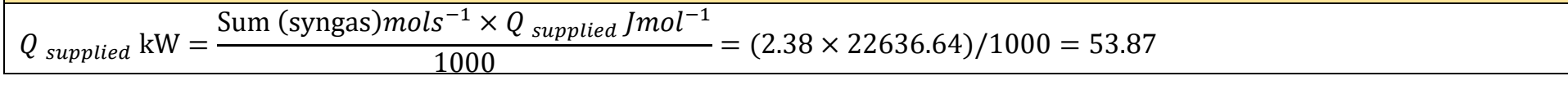 } \\
\hline
\end{tabular}


Efficiency $\left(\eta_{\mathrm{x}}\right)=\frac{\text { Energy }_{\text {out }}(J)}{\text { Energy }_{\text {in }}(J)}=\frac{\sum L H V_{\text {out }, a} m_{\text {out }, a}}{\sum L H V_{\text {in }, b} m_{\text {in }, b}+Q_{\text {supplied }}} \quad \mathrm{x} 100=\frac{296.13}{(598.55+53.87)} \times 100=45.38 \%$

\section{A5. Steam reforming (ATR) simulation datasets}

The auto-thermal methane steam reforming process was simulated on Aspen (Fig A5.1); more details on operating and feed conditions can be found in Table A5.1. Dry reforming and FT results along with FT efficiency calculations are presented in Table A5.2.

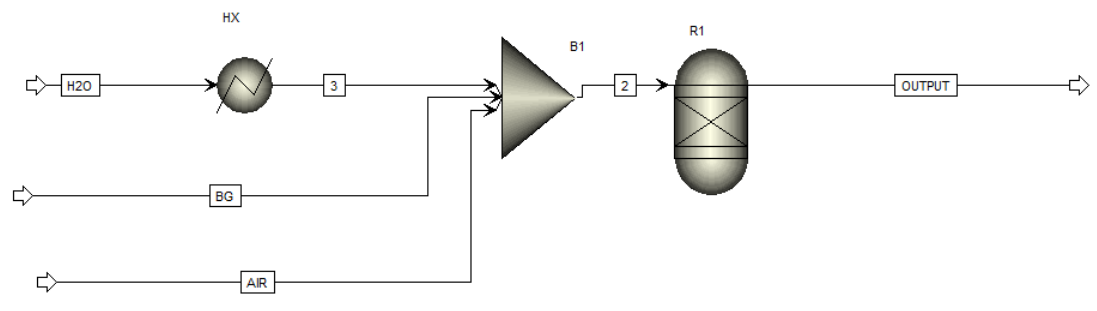

Figure A5.1: Steam reforming (ATR) Aspen simulation

Table A5.1: Aspen assumptions for steam reforming (ATR)

\begin{tabular}{|c|c|c|c|}
\hline Stream & Explanation & Symbol & Explanation \\
\hline Input & $\mathrm{CH}_{4}, \mathrm{H}_{2} \mathrm{O}$ and Air & $\mathrm{Hx}$ & Heater \\
\hline \multirow[t]{2}{*}{ Output } & $\mathrm{CO}$ and $\mathrm{H}_{2}$ & M1 & Mixer \\
\hline & & $\mathrm{R} 1$ & Gibbs reactor \\
\hline 2 & \multicolumn{3}{|c|}{ Air, $\mathrm{H}_{2} \mathrm{O}, \mathrm{CH}_{4}$ and $\mathrm{CO}_{2}$} \\
\hline 3 & \multicolumn{3}{|l|}{ Heated $\mathrm{H}_{2} \mathrm{O}$} \\
\hline \multicolumn{4}{|c|}{ Assumptions } \\
\hline \multicolumn{2}{|c|}{ Feed conditions } & \multicolumn{2}{|c|}{$\mathrm{H}_{2} \mathrm{O} / \mathrm{CH}_{4}: 3 / 1$ and $\mathrm{CH}_{4} 0.6$ mols $^{-1}$} \\
\hline \multicolumn{2}{|c|}{ Feed temperature } & \multicolumn{2}{|l|}{$25^{\circ} \mathrm{C}$} \\
\hline \multicolumn{2}{|c|}{ Feed pressure } & \multicolumn{2}{|l|}{1 bar } \\
\hline \multicolumn{2}{|c|}{ Process pressure } & \multicolumn{2}{|l|}{1 bar } \\
\hline \multicolumn{2}{|c|}{ Process temperature } & \multicolumn{2}{|l|}{$800^{\circ} \mathrm{C}$} \\
\hline \multicolumn{2}{|c|}{ Equation of state } & \multicolumn{2}{|c|}{ Peng Robinson } \\
\hline
\end{tabular}


Table A5.2: Steam reforming (ATR) and FT results, and FT efficiency calculations

\begin{tabular}{|c|c|c|c|c|c|c|c|c|c|c|}
\hline \multicolumn{9}{|c|}{ Steam reforming (ATR) } & & \\
\hline $\begin{array}{c}\text { Temperature } \\
\left({ }^{\circ} \mathrm{C}\right)\end{array}$ & Output & kmols $^{-1}$ & $\mathrm{kgkmol}^{-1}$ & $\mathrm{kgs}^{-1}$ & \multicolumn{2}{|c|}{ LHV } & $\mathrm{mols}^{-1}$ & \multirow{2}{*}{$\frac{\mathrm{kJs}^{-1}}{51.90}$} & & \\
\hline 798.27 & $\mathrm{CO}$ & 0.000200 & 28 & 0.005133 & $\mathrm{MJkg}^{-1}$ & kJmol-1 & 0.18 & & & \\
\hline Efficiency & $\mathrm{H}_{2}$ & 0.001000 & 2 & 0.001940 & 10.11 & 283.13 & 0.97 & 232.77 & & \\
\hline 59.55 & Sum & & & 0.007074 & 119.96 & 239.92 & 1.53 & 284.67 & & \\
\hline \multicolumn{11}{|c|}{ Fischer Tropsch } \\
\hline \multicolumn{11}{|c|}{ Average } \\
\hline Products & & Weight \% & & $\mathrm{kgs}^{-1}$ & \multicolumn{2}{|c|}{$\mathrm{kgmol}^{-1}$} & \multicolumn{2}{|c|}{$\mathrm{mols}^{-1}$} & $\mathrm{kJmol}^{-1}$ & $\mathrm{kJs}^{-1}$ \\
\hline $\mathrm{C}_{5}-\mathrm{C}_{10}$ & & 12.00 & & 0.000849 & \multicolumn{2}{|c|}{0.107217} & \multicolumn{2}{|c|}{0.007917} & 4774.63 & 37.80 \\
\hline $\mathrm{C}_{11}-\mathrm{C}_{22}$ & & 20.80 & & 0.001471 & \multicolumn{2}{|c|}{0.233458} & \multicolumn{2}{|c|}{0.006302} & 10382.02 & 65.43 \\
\hline Sum & & 32.80 & & - & & - & & - & - & 103.23 \\
\hline \multicolumn{11}{|c|}{ Efficiency Calculation } \\
\hline \multicolumn{11}{|c|}{ 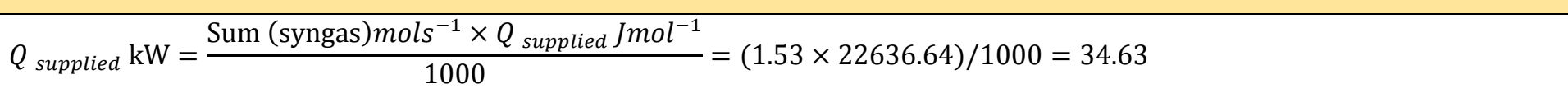 } \\
\hline Efficiency $\left(\eta_{x}\right)=$ & $\frac{\text { Energy }_{\text {out }}}{\text { Energy }_{\text {in }}}$ & $\frac{(J)}{(J)}=\frac{\sum}{\sum L H V_{i}}$ & $\frac{V_{\text {out }, a} m_{\text {out }}}{m_{\text {in }, b}+Q_{s u}}$ & lpplied & \multicolumn{4}{|c|}{$\mathrm{x} 100=\frac{103.23}{(284.67+34.63)} \times 100=32.33 \%$} & & \\
\hline
\end{tabular}

\section{A6. Tri reforming simulation datasets}

The tri reforming process was simulated on Aspen (Fig A6.1); more details on operating and feed conditions can be found in Table A6.1. Dry reforming and FT results along with FT efficiency calculations are presented in Table A6.2.

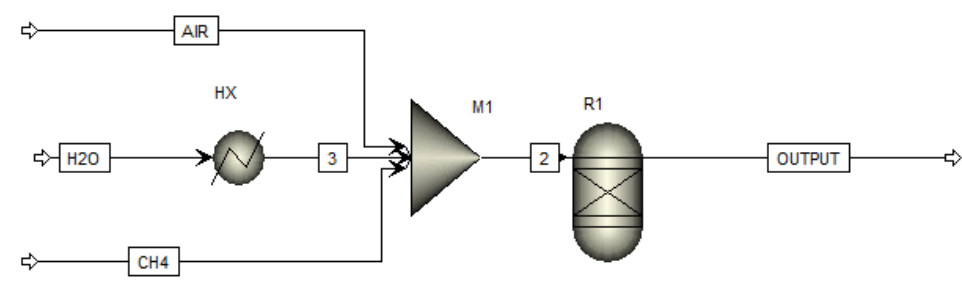

Fig A6.1: Tri reforming (ATR) Aspen simulation

Table A6.1: Aspen assumptions for tri reforming

\begin{tabular}{llll}
\hline Stream & Explanation & Symbol & Explanation \\
\hline Input & Air, $\mathrm{CH}_{4}, \mathrm{CO}_{2}$ and $\mathrm{H}_{2} \mathrm{O}$ & $\mathrm{Hx}$ & Heater \\
\hline Output & $\mathrm{CO}$ and $\mathrm{H}_{2}$ & $\mathrm{~B} 1$ & Mixer \\
\hline
\end{tabular}




\begin{tabular}{|c|c|c|c|}
\hline 3 & Heated $\mathrm{H}_{2} \mathrm{O}$ & $\mathrm{R} 1$ & Gibbs reactor \\
\hline BG & \multicolumn{3}{|l|}{$\mathrm{CH}_{4}$ and $\mathrm{CO}_{2}$} \\
\hline \multicolumn{4}{|c|}{ Assumptions } \\
\hline Feec & ions & $\mathrm{CO}_{2} / \mathrm{C}$ & and $1 \mathrm{mols}^{-1}$ \\
\hline & rature & $25^{\circ} \mathrm{C}$ & \\
\hline Feec & & 1 bar & \\
\hline Proc & ssure & 1 bar & \\
\hline Proc & perature & $800^{\circ} \mathrm{C}$ & \\
\hline Equa & state & Peng & son \\
\hline
\end{tabular}

Table A6.2: Tri reforming and FT results, and FT efficiency calculations

\section{Tri reforming}

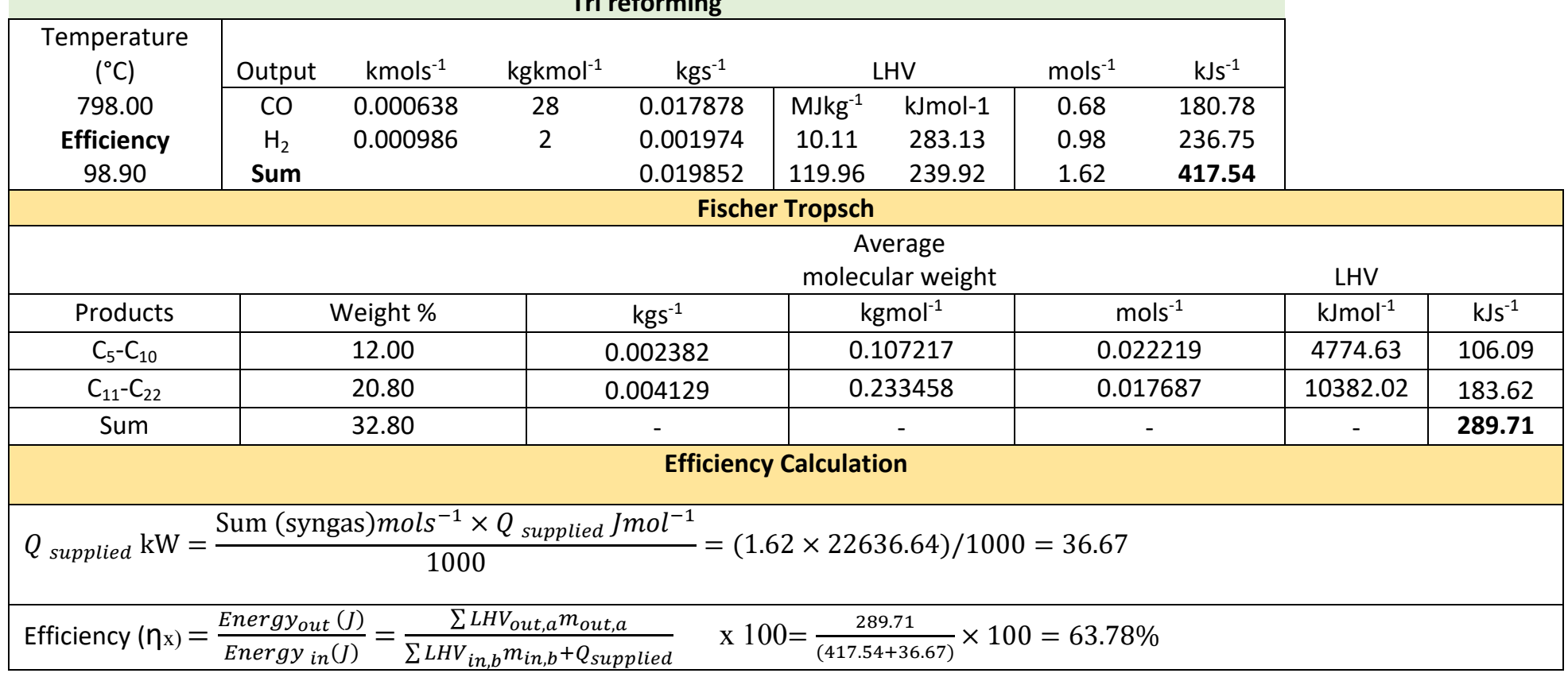

\section{A7. Tri reforming (ATR) simulation datasets}

The auto-thermal tri reforming process was simulated on Aspen (Fig A7.1); more details on operating and feed conditions can be found in Table A7.1. Dry reforming and FT results along with FT efficiency calculations are presented in Table A7.2. 


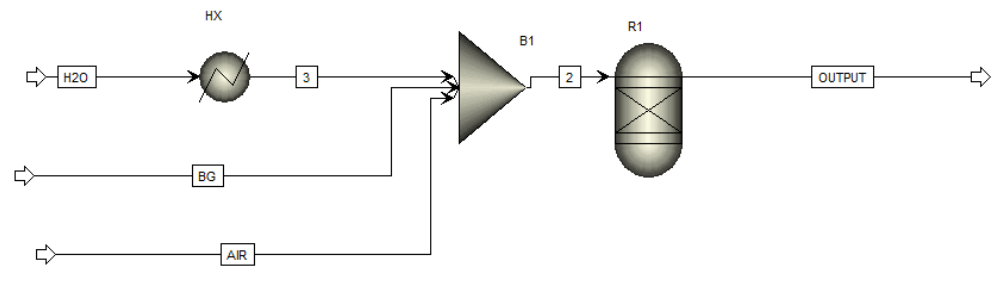

Figure A7.1: Tri reforming (ATR) Aspen simulation

Table A7.1: Aspen assumptions for tri reforming (ATR)

\begin{tabular}{|c|c|c|c|}
\hline Stream & Explanation & Symbol & Explanation \\
\hline Input & Air, $\mathrm{CH}_{4}, \mathrm{CO}_{2}$ and $\mathrm{H}_{2} \mathrm{O}$ & $H x$ & Heater \\
\hline Output & $\mathrm{CO}$ and $\mathrm{H}_{2}$ & B1 & Mixer \\
\hline 3 & Heated $\mathrm{H}_{2} \mathrm{O}$ & $\mathrm{R} 1$ & Gibbs reactor \\
\hline BG & \multicolumn{3}{|l|}{$\mathrm{CH}_{4}$ and $\mathrm{CO}_{2}$} \\
\hline \multicolumn{4}{|c|}{ Assumptions } \\
\hline \multicolumn{2}{|c|}{ Feed conditions } & \multicolumn{2}{|c|}{$\mathrm{CO}_{2} / \mathrm{CH}_{4}: 2 / 3$ and $1 \mathrm{mols}^{-1}$} \\
\hline \multicolumn{2}{|c|}{ Feed temperature } & \multicolumn{2}{|l|}{$25^{\circ} \mathrm{C}$} \\
\hline \multicolumn{2}{|c|}{ Feed pressure } & \multicolumn{2}{|l|}{1 bar } \\
\hline \multicolumn{2}{|c|}{ Process pressure } & \multicolumn{2}{|l|}{1 bar } \\
\hline \multicolumn{2}{|c|}{ Process temperature } & \multicolumn{2}{|l|}{$800^{\circ} \mathrm{C}$} \\
\hline \multicolumn{2}{|c|}{ Equation of state } & \multicolumn{2}{|c|}{ Peng Robinson } \\
\hline
\end{tabular}

Table A7.2: Tri reforming (ATR) and FT results, and FT efficiency calculations

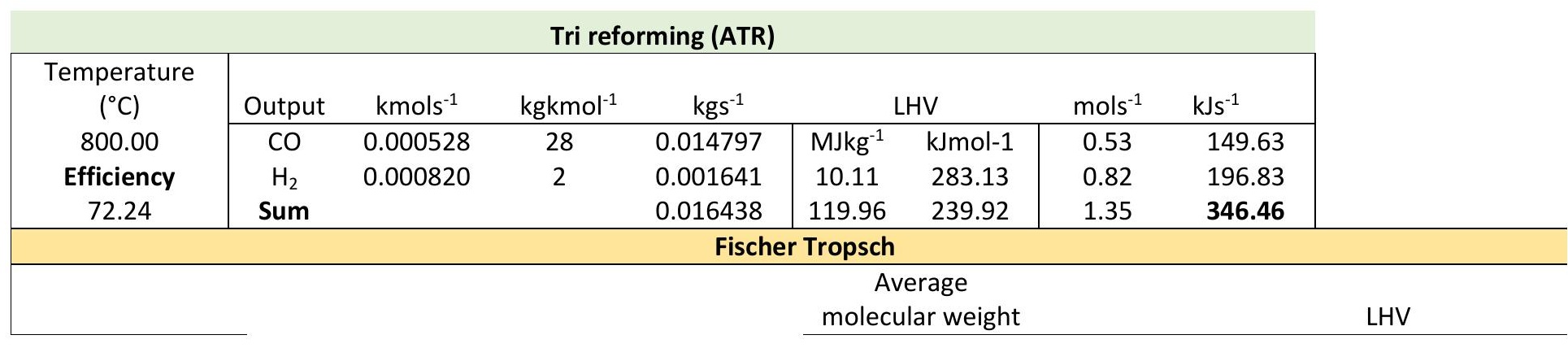




\begin{tabular}{|c|c|c|c|c|c|c|}
\cline { 2 - 3 } & Weight \% & $\mathrm{kgs}^{-1}$ & $\mathrm{kgmol}^{-1}$ & $\mathrm{mols}^{-1}$ & $\mathrm{kJs}^{-1}$ \\
\hline $\mathrm{C}_{5}-\mathrm{C}_{10}$ & 12.00 & 0.001973 & 0.107217 & 0.018398 & 4774.63 & 87.84 \\
\hline $\mathrm{C}_{11}-\mathrm{C}_{22}$ & 20.80 & 0.003419 & 0.233458 & 0.014645 & 10382.02 & 152.04 \\
\hline Sum & 32.80 & - & - & - & - & $\mathbf{2 3 9}$ \\
\hline
\end{tabular}

Efficiency Calculation

$Q_{\text {supplied }} \mathrm{kW}=\frac{\text { Sum (syngas) } \mathrm{mols}^{-1} \times Q_{\text {supplied }} \mathrm{Jmol}^{-1}}{1000}=(1.35 \times 22636.64) / 1000=30.55$

Efficiency $\left(\eta_{\mathrm{x}}\right)=\frac{\text { Energy }_{\text {out }}(J)}{\text { Energy }_{\text {in }}(J)}=\frac{\sum L H V_{\text {out }, a} m_{\text {out }, a}}{\sum L H V_{\text {in, }} m_{\text {in }, b}+Q_{\text {supplied }}} \quad \mathrm{x} 100=\frac{239.89}{(346.46+30.55)} \times 100=63.62 \%$

\section{B: Material and heat balance examples \\ B1. Dry reforming (ATR)}

An example of the heat and material balance generated from the Aspen simulation is presented in

Table B1.1.

Table B1.1: Dry reforming (ATR) material and heat balance

\begin{tabular}{|c|c|c|c|c|}
\hline Dry reforming (ATR) & 3 & AIR & INPUT & OUTPUT \\
\hline Substream: MIXED & & & & \\
\hline \multicolumn{5}{|l|}{ Mole Flow kmols-1 } \\
\hline $\mathrm{CH}_{4}$ & 0.0006 & 0 & 0.0006 & 9.53E-07 \\
\hline $\mathrm{CO}_{2}$ & 0.0004 & 0 & 0.0004 & $2.52 \mathrm{E}-04$ \\
\hline $\mathrm{CO}$ & 0 & 0 & 0 & 7.47E-04 \\
\hline $\mathrm{H}_{2}$ & 0 & 0 & 0 & $9.14 \mathrm{E}-04$ \\
\hline $\mathrm{C}$ & 0 & 0 & 0 & 0 \\
\hline $\mathrm{O}_{2}$ & 0 & 0.00036759 & 0 & $1.51 \mathrm{E}-22$ \\
\hline $\mathrm{N}_{2}$ & 0 & 0.00138286 & 0 & 0.00138286 \\
\hline $\mathrm{H}_{2} \mathrm{O}$ & 0 & 0 & 0 & 0.000284 \\
\hline Total Flow kmols ${ }^{-1}$ & 0.001 & 0.00175046 & 0.001 & 0.00358096 \\
\hline Total Flow $\mathrm{kgs}^{-1}$ & 0.02722957 & 0.05050165 & 0.02722957 & 0.07773122 \\
\hline Total Flow $\mathrm{m}^{3} \mathrm{~s}^{-1}$ & 0.08807937 & 0.04280199 & 0.02438617 & 0.31540861 \\
\hline Temperature $\mathrm{K}$ & 1073.15 & 298.15 & 298.15 & 1073.15 \\
\hline Pressure $\mathrm{Nm}^{-2}$ & 101325 & 101325 & 101325 & 101325 \\
\hline Vapor Frac & 1 & 1 & 1 & 1 \\
\hline Liquid Frac & 0 & 0 & 0 & 0 \\
\hline Solid Frac & 0 & 0 & 0 & 0 \\
\hline Enthalpy $\mathrm{Jkmol}^{-1}$ & -160838523 & -8146.4149 & -202141348 & -44918741 \\
\hline Enthalpy Jkg ${ }^{-1}$ & -5906758.3 & -282.36751 & -7423595.1 & -2069340 \\
\hline Enthalpy Watt & -160838.52 & -14.260026 & -202141.35 & -160852.34 \\
\hline Entropy $\mathrm{Jkmol}^{-1} \mathrm{~K}^{-1}$ & 22293.5095 & 4250.39851 & -41667.008 & 67928.7902 \\
\hline Entropy $\mathrm{Jkg}^{-1} \mathrm{~K}^{-1}$ & 818.724079 & 147.325476 & -1530.2114 & 3129.37888 \\
\hline Density kmolm³ & 0.01135339 & 0.04089684 & 0.04100684 & 0.0113534 \\
\hline Density $\mathrm{kgm}^{-3}$ & 0.30914816 & 1.17989013 & 1.11659897 & 0.24644612 \\
\hline Average MW & 27.229576 & 28.8503972 & 27.229576 & 21.7067964 \\
\hline
\end{tabular}




\section{B2. Steam reforming (ATR)}

An example of the heat and material balance generated from Aspen simulation is presented in Table B2.1.

Table B2.1: Steam reforming (ATR) material and heat balance

\begin{tabular}{|c|c|c|c|c|c|c|}
\hline Steam reforming (ATR) & 2 & 3 & AIR & $\mathrm{CH}_{4}$ & $\mathrm{H}_{2} \mathrm{O}$ & OUTPUT \\
\hline \multicolumn{7}{|l|}{ Substream: MIXED } \\
\hline Mole Flow kmols ${ }^{-1}$ & & & & & & \\
\hline $\mathrm{CH}_{4}$ & 0.0006 & 0 & 0 & 0.0006 & 0 & $1.42 \mathrm{E}-08$ \\
\hline $\mathrm{CO}$ & 0 & 0 & 0 & 0 & 0 & 1.83E-04 \\
\hline $\mathrm{H}_{2}$ & 0 & 0 & 0 & 0 & 0 & $9.70 \mathrm{E}-04$ \\
\hline C & 0 & 0 & 0 & 0 & 0 & $0.00 E+00$ \\
\hline $\mathrm{H}_{2} \mathrm{O}$ & 0.0018 & 0.0018 & 0 & 0 & 0.0018 & 0.00202974 \\
\hline $\mathrm{O}_{2}$ & $6.23 E-04$ & 0 & $6.23 \mathrm{E}-04$ & 0 & 0 & $1.14 \mathrm{E}-20$ \\
\hline $\mathrm{N}_{2}$ & $2.34 \mathrm{E}-03$ & 0 & $2.34 \mathrm{E}-03$ & 0 & 0 & $2.34 \mathrm{E}-03$ \\
\hline $\mathrm{CO}_{2}$ & 0 & 0 & 0 & 0 & 0 & 4.17E-04 \\
\hline Total Flow kmols ${ }^{-1}$ & 0.00536757 & 0.0018 & $2.97 \mathrm{E}-03$ & 0.0006 & 0.0018 & 0.00594435 \\
\hline Total Flow $\mathrm{kgs}^{-1}$ & 0.12766882 & 0.0324275 & 0.08561566 & 0.00962565 & 0.0324275 & 0.12766882 \\
\hline Total Flow $\mathrm{m}^{3} \mathrm{~s}^{-1}$ & 0.15036044 & 0.05613315 & 0.0725624 & 0.01464606 & $3.26 \mathrm{E}-05$ & 0.52354165 \\
\hline Temperature $\mathrm{K}$ & 346.847411 & 383.15 & 298.15 & 298.15 & 298.15 & 1073.15 \\
\hline Pressure $\mathrm{Nm}^{-2}$ & 101325 & 101325 & 101325 & 101325 & 101325 & 101325 \\
\hline Vapor Frac & 0.98669628 & 1 & 1 & 1 & 0 & 1 \\
\hline Liquid Frac & 0.01330371 & 0 & 0 & 0 & 1 & 0 \\
\hline Solid Frac & 0 & 0 & 0 & 0 & 0 & 0 \\
\hline Enthalpy $\mathrm{Jkmol}^{-1}$ & -88487504 & -239008868 & -8146.4149 & -74538332 & -287737387 & -87129230 \\
\hline Enthalpy $\mathrm{Jkg}^{-1}$ & -3720275.1 & -13267008 & -282.36751 & -4646228.7 & -15971852 & -4056801.1 \\
\hline Enthalpy Watt & -474963.14 & -430215.96 & -24.175081 & -44722.999 & -517927.3 & -517927.01 \\
\hline Entropy $\mathrm{Jkmol}^{-1} \mathrm{~K}^{-1}$ & -10654.721 & -35987.795 & 4250.39851 & -80639.826 & -167900.04 & 41661.9407 \\
\hline Entropy $\mathrm{Jkg}^{-1} \mathrm{~K}^{-1}$ & -447.95582 & -1997.6262 & 147.325476 & -5026.5556 & -9319.8684 & 1939.81063 \\
\hline Density $\mathrm{kmolm}^{-3}$ & 0.03569804 & 0.03206661 & 0.04089684 & 0.04096663 & 55.1729976 & 0.01135411 \\
\hline Density kgm ${ }^{-3}$ & 0.8490852 & 0.57768898 & 1.17989013 & 0.65721794 & 993.957 & 0.24385609 \\
\hline Average MW & 23.7852042 & 18.01528 & 28.8503972 & 16.04276 & 18.01528 & 21.4773236 \\
\hline Liq Vol $60 \mathrm{~F} \mathrm{~m}^{3} \mathrm{~s}^{-1}$ & $2.24 \mathrm{E}-04$ & $3.25 \mathrm{E}-05$ & $1.59 \mathrm{E}-04$ & $3.21 \mathrm{E}-05$ & $3.25 \mathrm{E}-05$ & 2.46E-04 \\
\hline
\end{tabular}




\section{B3. Tri reforming (ATR)}

An example of the heat and material balance generated from Aspen simulation is presented in Table B3.1.

Table B3.1: Tri reforming (ATR) material and heat balance

\begin{tabular}{|c|c|c|c|c|c|c|}
\hline \multirow{2}{*}{\multicolumn{7}{|c|}{$\begin{array}{l}\text { Tri reforming (ATR) } \\
\text { Substream: MIXED }\end{array}$}} \\
\hline & & & & & & \\
\hline \multicolumn{7}{|l|}{ Mole Flow kmols ${ }^{-1}$} \\
\hline $\mathrm{CH}_{4}$ & 0.0006 & 0 & 0 & 0.0006 & 0 & $6.73 \mathrm{E}-08$ \\
\hline $\mathrm{CO}$ & 0 & 0 & 0 & 0 & 0 & 0.00052847 \\
\hline $\mathrm{H}_{2}$ & 0 & 0 & 0 & 0 & 0 & 0.00082041 \\
\hline C & 0 & 0 & 0 & 0 & 0 & 0 \\
\hline $\mathrm{H}_{2} \mathrm{O}$ & 0.00064654 & 0.00064654 & 0 & 0 & 0.00064654 & 0.00102599 \\
\hline $\mathrm{CO}_{2}$ & 0.00064654 & 0 & 0 & 0.00064654 & 0 & 0.000718 \\
\hline $\mathrm{O}_{2}$ & 0.00052542 & 0 & 0.00052542 & 0 & 0 & $3.46 \mathrm{E}-21$ \\
\hline $\mathrm{N}_{2}$ & 0.00197658 & 0 & 0.00197658 & 0 & 0 & 0.00197658 \\
\hline Total Flow kmols ${ }^{-1}$ & 0.00439509 & 0.00064654 & 0.002502 & 0.00124654 & 0.00064654 & 0.00506954 \\
\hline Total Flow $\mathrm{kgs}^{-1}$ & 0.12191162 & 0.01164769 & 0.07218392 & 0.03807999 & 0.01164769 & 0.12191162 \\
\hline Total Flow $\mathrm{m}^{3} \mathrm{~s}^{-1}$ & 0.11667416 & 0.02016257 & 0.06117851 & 0.03038692 & 1.17E-05 & 0.44651229 \\
\hline Temperature $\mathrm{K}$ & 328.123872 & 383.15 & 298.15 & 298.15 & 298.15 & 1073.15 \\
\hline Pressure $\mathrm{Nm}^{-2}$ & 101325 & 101325 & 101325 & 101325 & 101325 & 101325 \\
\hline Vapor Frac & 0.98774968 & 1 & 1 & 1 & 0 & 1 \\
\hline Liquid Frac & 0.01225031 & 0 & 0 & 0 & 1 & 0 \\
\hline Solid Frac & 0 & 0 & 0 & 0 & 0 & 0 \\
\hline Enthalpy $\mathrm{Jkmol}^{-1}$ & 103233065 & -239008868 & -8146.4149 & -239998519 & -287737387 & -89498974 \\
\hline Enthalpy $\mathrm{Jkg}^{-1}$ & -3721708.8 & -13267008 & -282.36751 & -7856332 & -15971852 & -3721703.3 \\
\hline Enthalpy Watt & -453719.54 & -154530.1 & -20.382396 & -299169.06 & -186035.3 & -453718.86 \\
\hline Entropy $\mathrm{Jkmol}^{-1} \mathrm{~K}^{-1}$ & -3673.97 & -35987.795 & 4250.39851 & -31604.575 & -167900.04 & 56428.7007 \\
\hline Entropy $\mathrm{Jkg}^{-1} \mathrm{~K}^{-1}$ & -132.4522 & -1997.6262 & 147.325476 & -1034.5732 & -9319.8684 & 2346.51717 \\
\hline Density kmolm-3 & 0.03766985 & 0.03206661 & 0.04089684 & 0.04102242 & 55.1729976 & 0.01135364 \\
\hline Density kgm ${ }^{-3}$ & 1.04488963 & 0.57768898 & 1.17989013 & 1.25317026 & 993.957 & 0.27303082 \\
\hline Average MW & 27.7380821 & 18.01528 & 28.8503972 & 30.5484184 & 18.01528 & 24.0478533 \\
\hline Liq Vol $60 \mathrm{~F} \mathrm{~m}^{3} \mathrm{~s}^{-1}$ & 0.00021243 & 1.17E-05 & 0.000134 & $6.68 \mathrm{E}-05$ & 1.17E-05 & 0.00023508 \\
\hline
\end{tabular}

\section{Supplementary data references}

[1] Jahangiri, H., et al., A review of advanced catalyst development for Fischer-Tropsch synthesis of hydrocarbons from biomass derived syn-gas. Catalysis Science \& Technology, 2014. 4(8): p. 2210-2229.

[2] Ashraf, M.T., J.-R. Bastidas-Oyanedel, and A. Schmidt, Conversion Efficiency of Biogas to Liquids Fuels through Fischer-Tropsch Process. 2015.

[3] Maitlis, P.M., in Greener Fischer Tropsch Processes for Fuels and Feedstocks, P.M. Maitlis and A. de Klerk, Editors. 2013, Wiley-VCH. 
[4] Jechura, J. Pure Component Data (API). [Online]. Available: http://inside.mines.edu/ jiechura/Common/PureComponentData.xls [Accessed: 16-052017] 